\title{
التوافق النفسي لاى أطفال الرياض وعلاقته بالسلوك العدواني
}

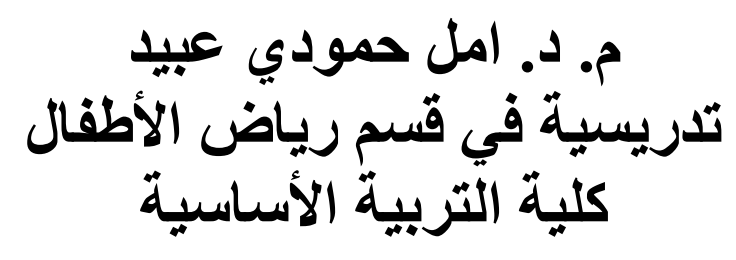

\section{ملخص البحث}

يستهدف البحث الحالي إلى الكثف عن التوافق النفسي لدى أطفال الرياض وعلاقته بالسلوك

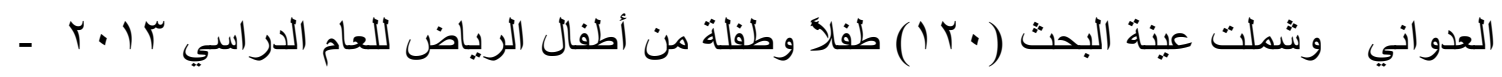

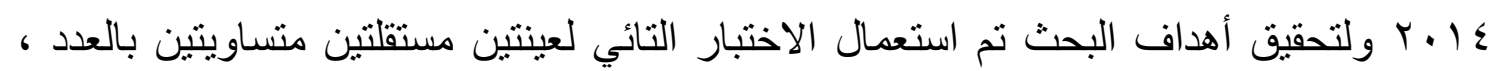
و استخدام الاختبار التائي لعينة واحدة لقياس التوافق النفسي وقياس السلوك العدواني واستعمال

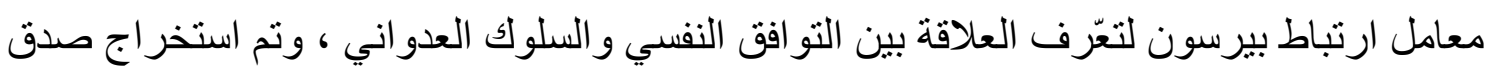

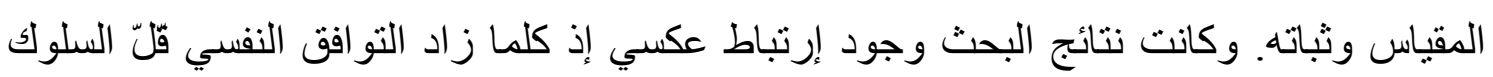

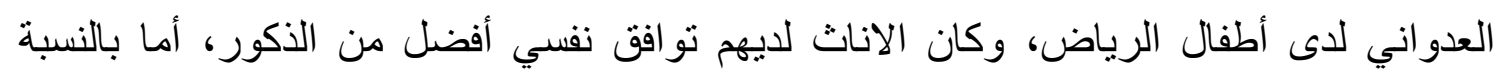

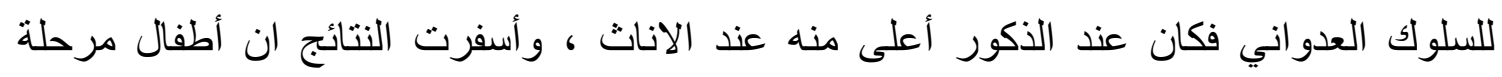
الروضة لايهم نو افق نفسي و عدم وجود سلوك عدو اني لديهم بعكس أطفال مرحلة التمهيدي. و أخير أ قدمت الباحثة بعض التوصيات و المقترحات لدر اسات أخرى.

\section{Research Summary}

Targeting the current research is to detect psychological adjustment among children Riyadh and its relationship to aggressive behavior included research sample (120) children from children Riyadh for the academic year 2013-2014 and to achieve the objectives of the research were used samples t-test for two independent samples of equal number, and the use of test samples $t$ for one sample to measure the psychological adjustment and measurement of aggressive behavior and the use of Pearson's correlation coefficient to know the relationship between psychological adjustment and aggressive behavior, was extracting reliability and validity. The research and having reverse correlation results as the greater psychological 
adjustment Say aggressive behavior in children Riyadh, was the female have myself better than males agree, but for aggressive behavior was when the male is higher than in females, and resulted in findings that children of kindergarten have myself compatibility and the lack of they have aggressive behavior of children, unlike the preliminary stage.

Finally, the researcher made some recommendations and suggestions for other studies.

\section{التعريف بالبحث}

أُولا : مشكلة ما البحث المدرسة من أهم المر احل العمرية التي يتم فيها غرس مقومات وملامح شخصية

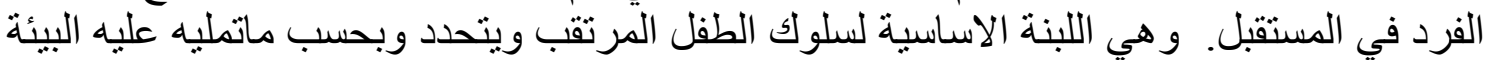

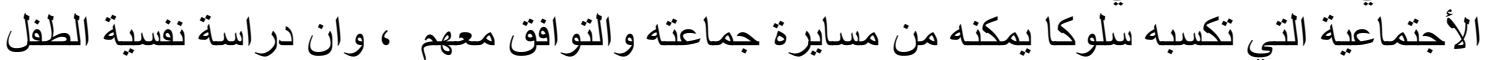

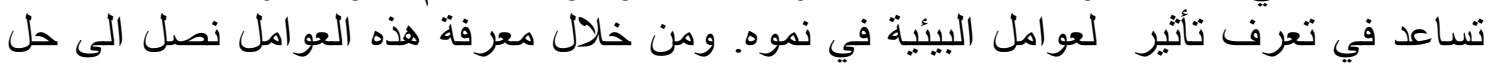

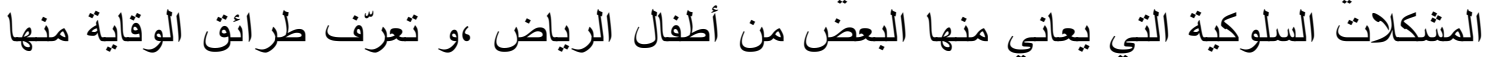

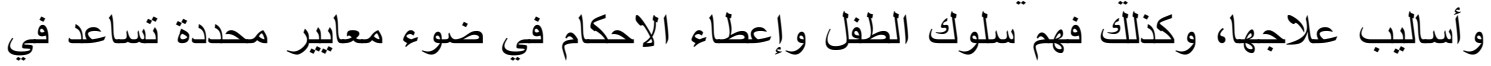

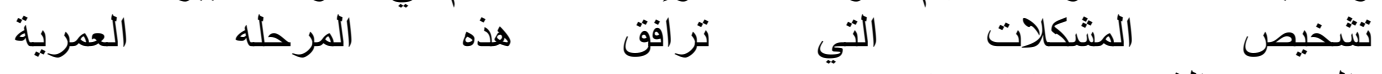

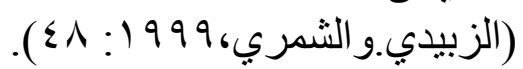

ور غم اهمية در اسة سلوك الطفل و العو امل البيئية المؤثرة في صحتة النفسية إلا ان الكثير من علماء

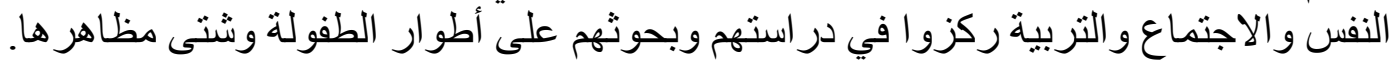

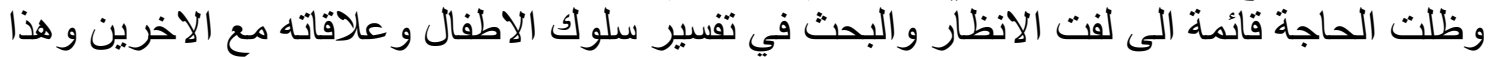

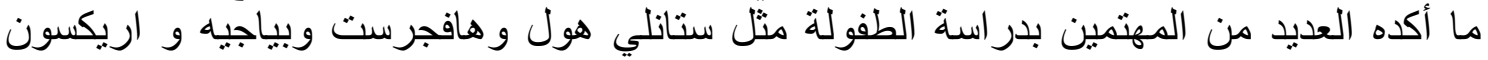

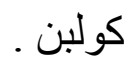

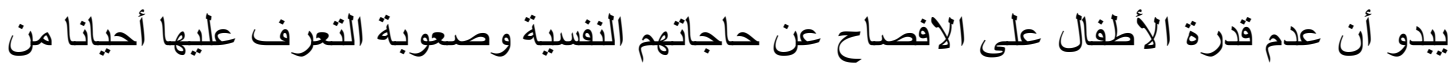

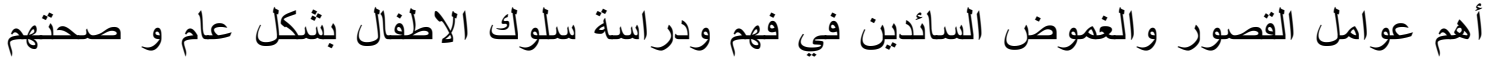

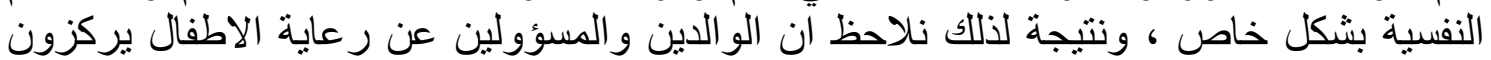

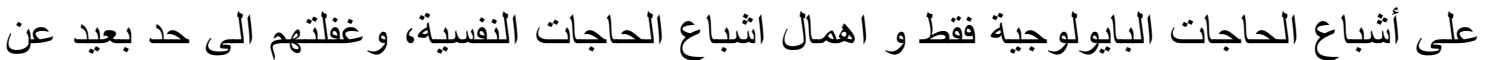

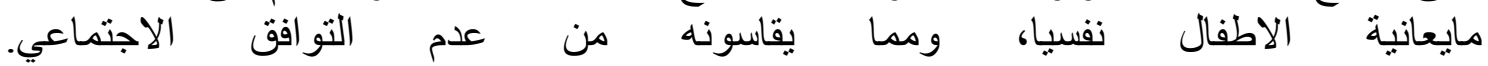

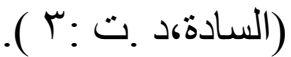

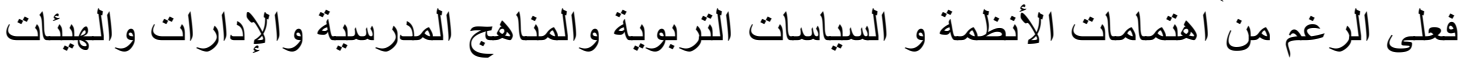

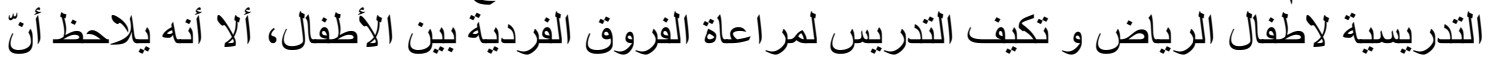

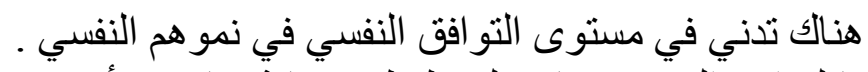

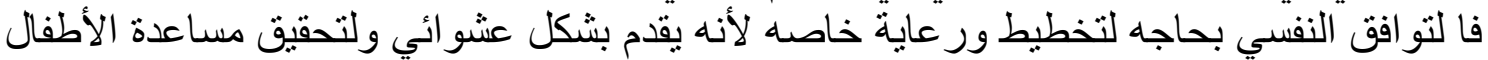

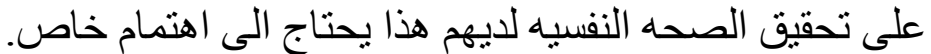

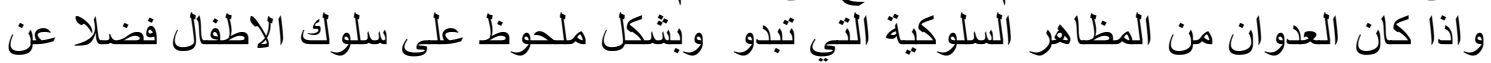

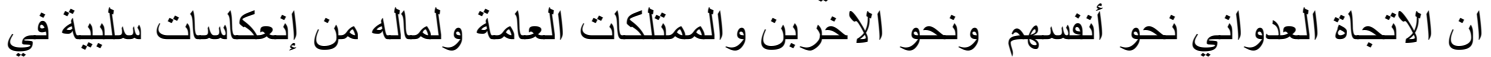

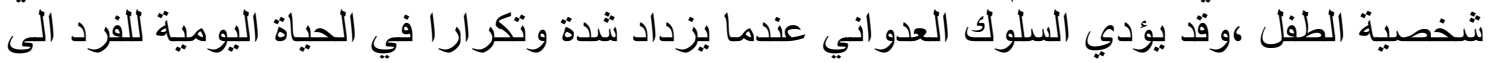


ولقد حظي السلوك العدواني باهتمام العديد من علماء النفس فقد أشنار مكدوكل الى ان العدوان

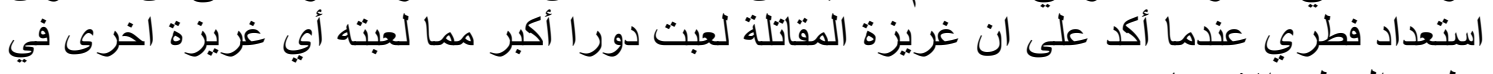

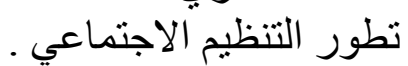
و أثنارت الدر اسات العلمية الى ان العدوان العان يرتبط بعداد من المتغيرات ففي مجال علاقة العدوان

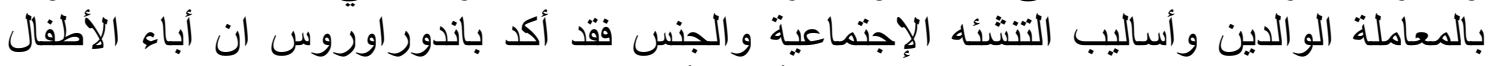

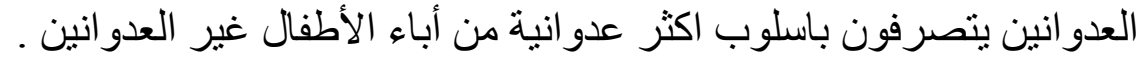

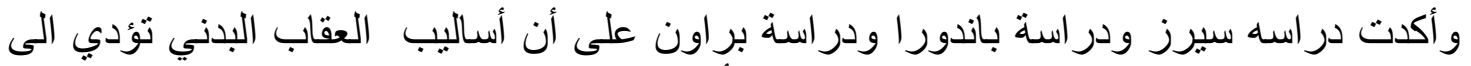

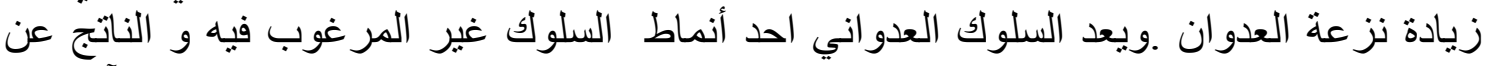
(الآلوسي،

اساليب التنشئه الاجتماعية الخاطئة . . (9: 1997 وبناء على ما تقدم فمشكله البحث الحالي يمكن تتحدد بالسؤ ال الآتي :-

(هل أنّ التوافق النفسي لطقل الروضة له علاقة بالسلوك العدواني بشكل ملحوظ) ؟

تكمن أهمية البحث الحالي في أهمية مرحلة الطفولة وأثرها في شخصيه الفرد سلبآ أو ايجابأ،

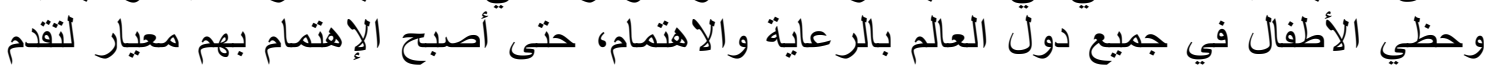

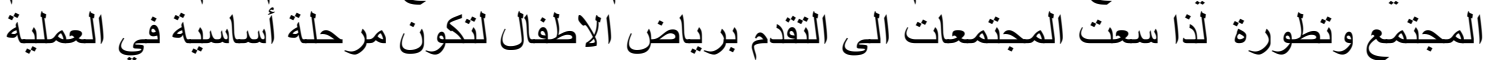

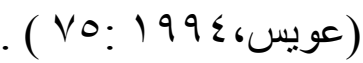

التربوية والاساس القورة في في السلم التعليمي.

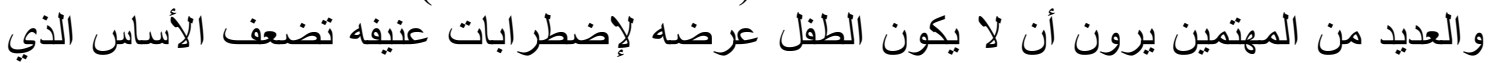

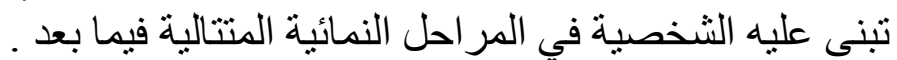

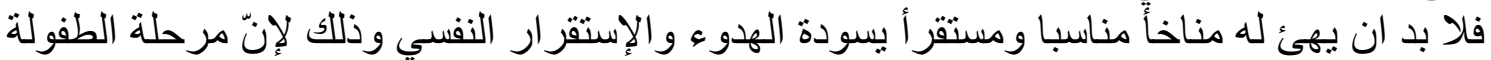

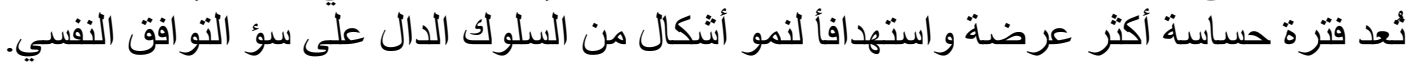

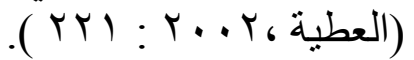

فدر اسة التو افق النفسي لطفل الروضه تتطلب در اسة العو امل التي تؤثر فيه وتساعد على أحداثه .

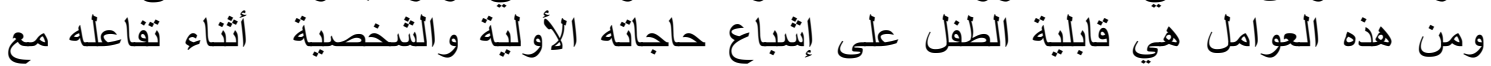

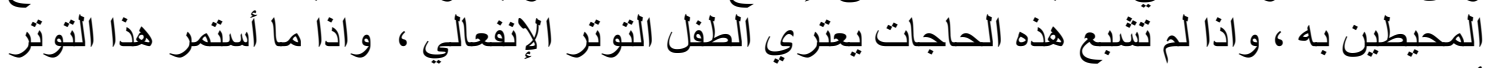

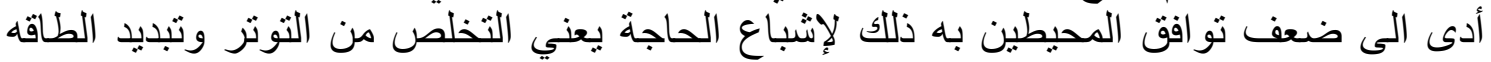

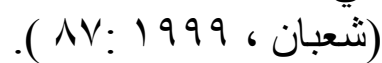

$$
\begin{aligned}
& \text { المحثوده و الرجوع الى حالة الإتز ان الانف النعالي. }
\end{aligned}
$$

و يرجع السلوك العدواني لدى الأطفال الى مفهوم السلبيية عن ذواتهم مما يجعلهم يفقدون الثقانه

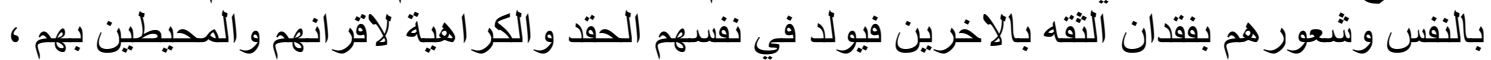

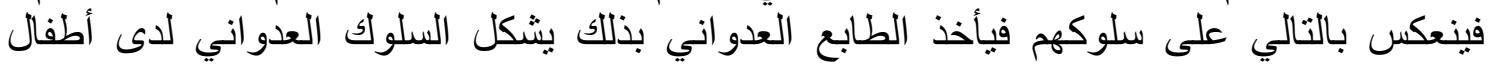

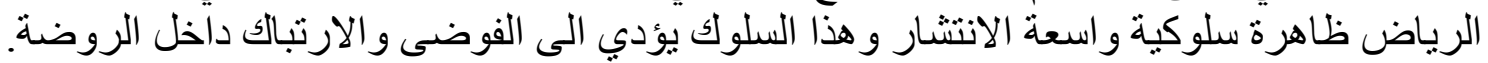

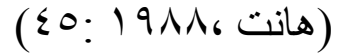
لذا رأت الباحثة أنّ هناك حاجه ملحه مله مثل هذه الدراسة للوقوف على مظاهر السلوك العدواني،

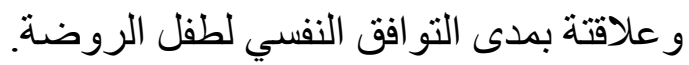


يستهدف البحث الحالي إلى التحقق من الفرضيات الاتية:-

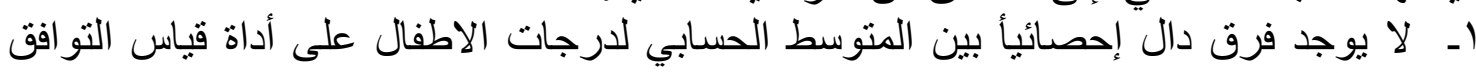

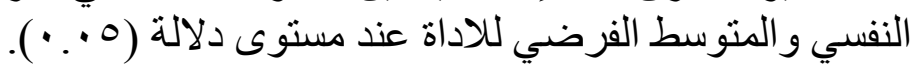

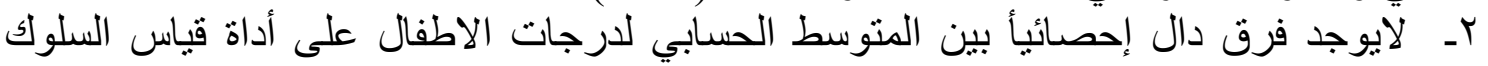

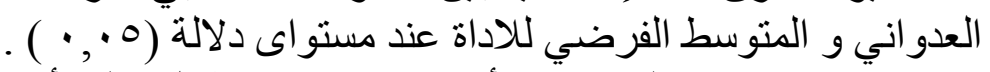

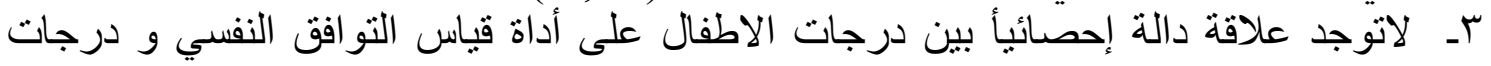

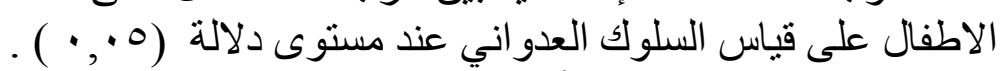

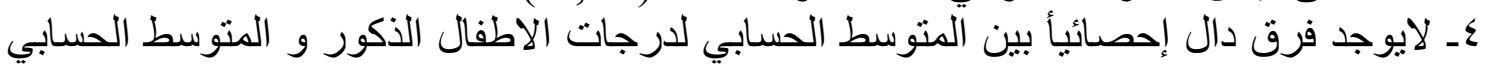

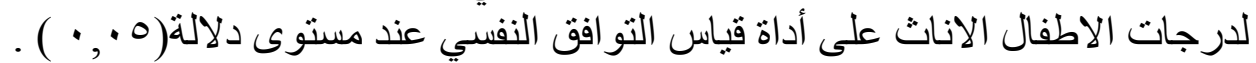

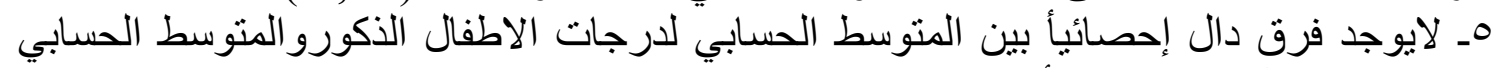

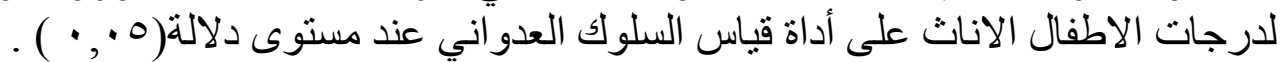

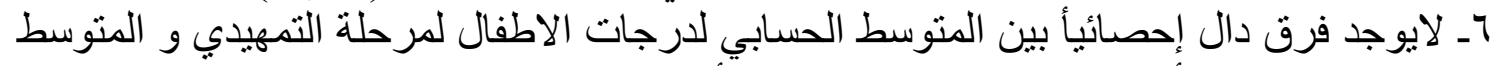

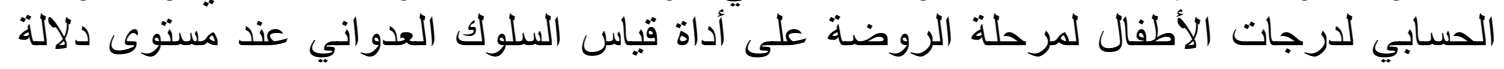
$(\cdot, \cdot 0)$

$$
\text { تحداً : حدود البحث : }
$$

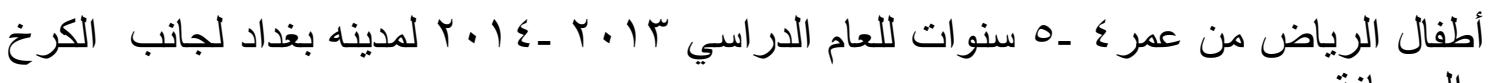
والرصافة

خامساً : تحديد المصطلحات :التوافق النفسي :عرفها كل من :-

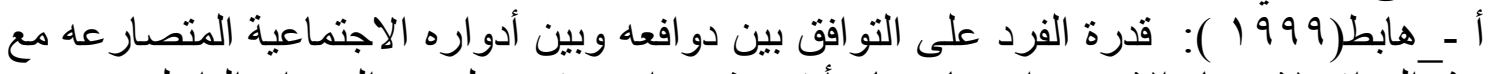

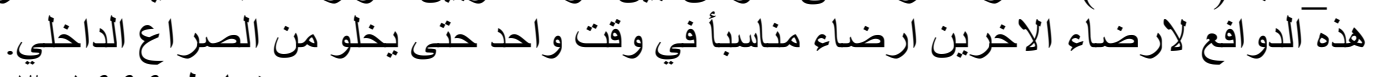

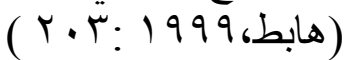

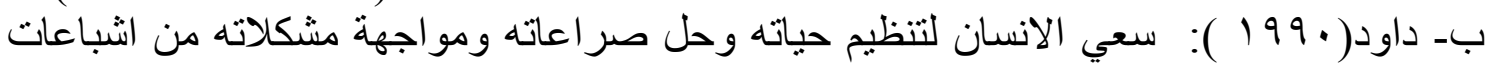

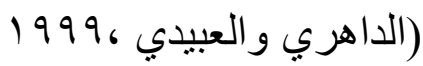

واحباطات وصو لا الى الصحه النفسيه.

( r.r:

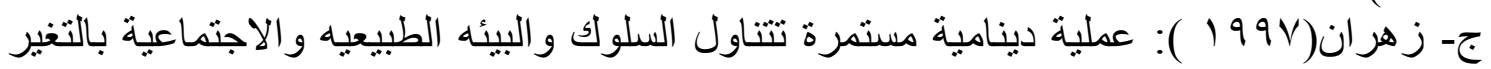

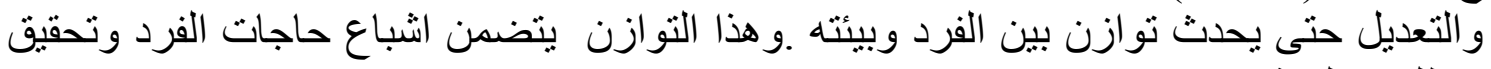

$$
\text { ( } r V: 199 V ، j \text { (j) }
$$

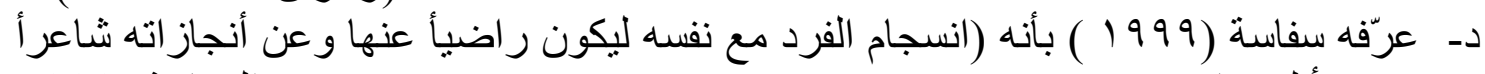

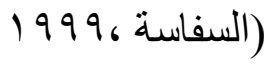

بقيمته محققأ لر غباته) 
أما التعريف الاجرائي للتو افق النفسي : (فهو الذي يقاس من خلال الدرجة الكلية التي يحصل عليها الطفل في المقياس الذي أعدته الباحثه لآغر اض هذه الفي الدر اسة).

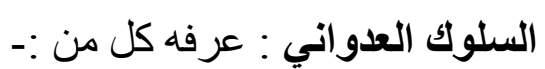

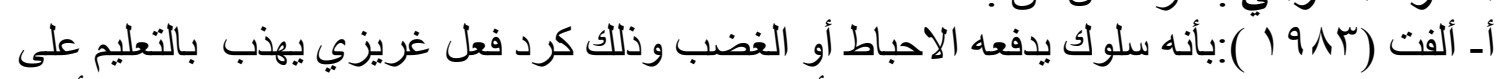
(ألفتى )

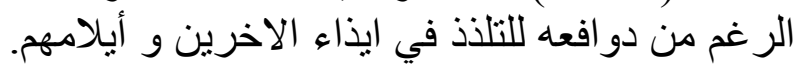
(V9: 19人 ب- طلعت منصور و أخرون (199 (199 ) ) عرفوا العدوان بأنه :

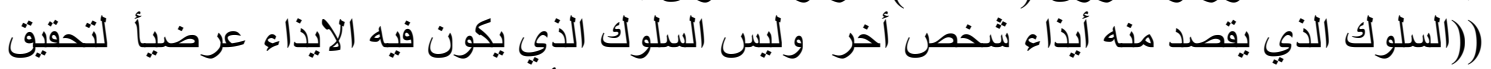

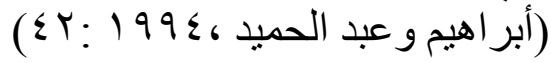

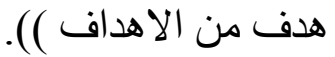

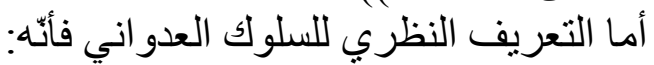

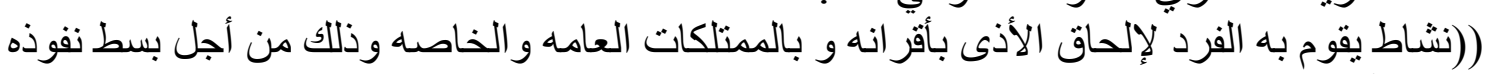
على الآخرين و التفوق عليهح وذلك بسب الإحباطات التي يو اجهها في حياته اليومية))

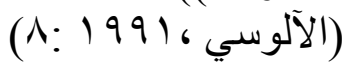
أما التعريف الإجرائي : فهو الدرجه الكليه التي يحصل عليها الطفل على مقياس السلولك العدواني و المعد لآغر اض هذا البح الآيث. طقل الروضة: عرفه كل من:-

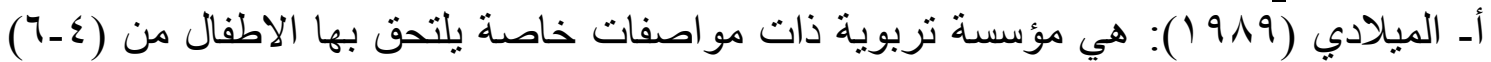

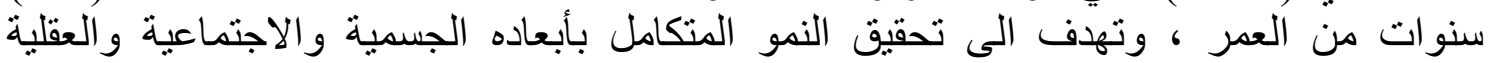

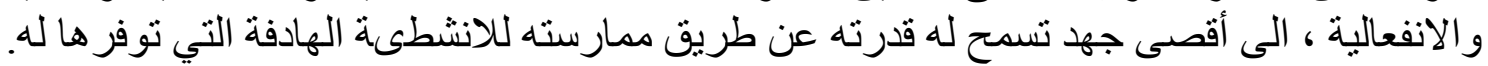

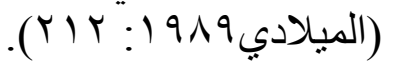

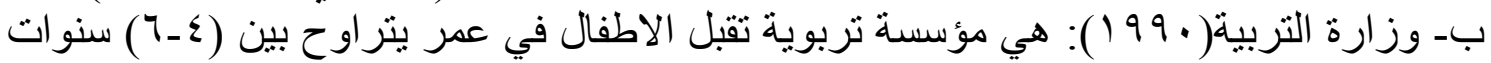

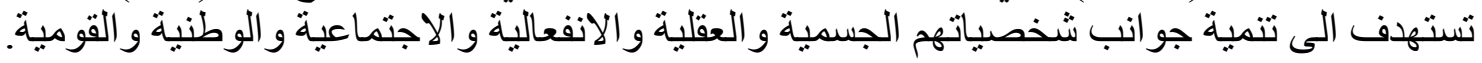

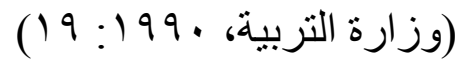

\section{الاطار النظري}

التوافق النفسي كما ير اه علماء النفس:

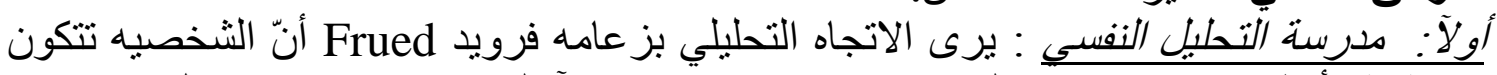

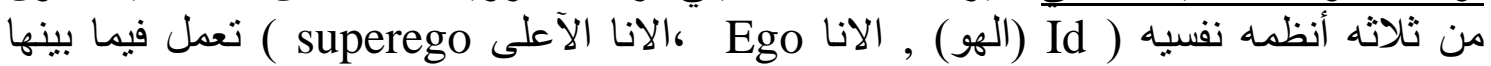

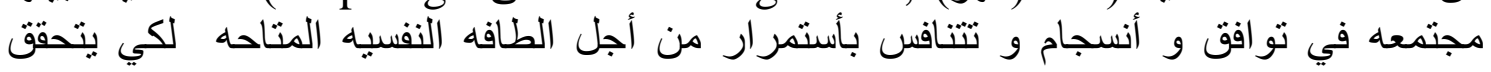

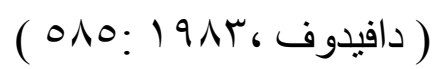
التوازن و الاستقر ار للفرد وخفض و أنو التوتر

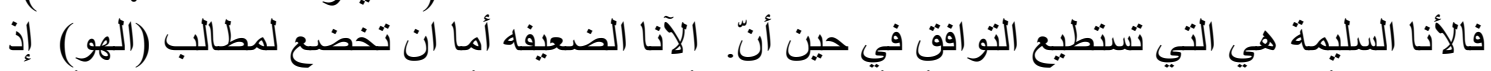

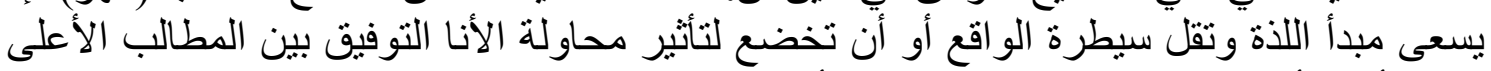

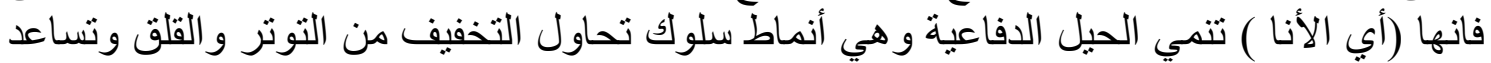
191 r. عباس الفرد في محاو لاتة للتو افق. (7.:

وتبدو- الهو- في مرحله الطفوله المبكرة مسيطرة على سلوك الطفل إذ بسعى لتحقيق حاجاتة

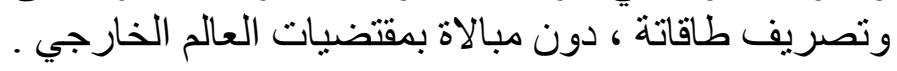


أما ـ الأنا ـ فتنثق منها خلال العام الثاني للنمو ويستمر مع الحياة حيث يبدألطفل بالتعامل مع

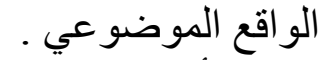

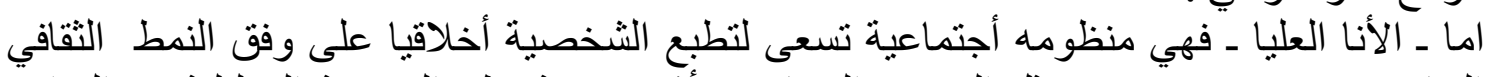

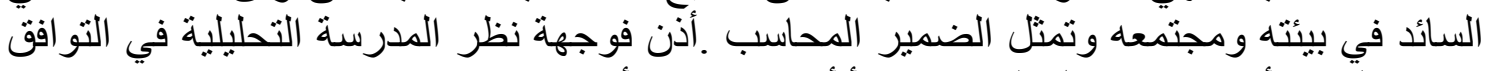

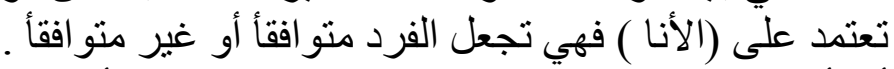

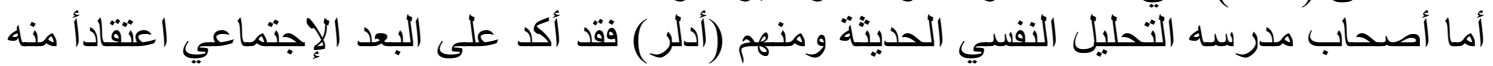

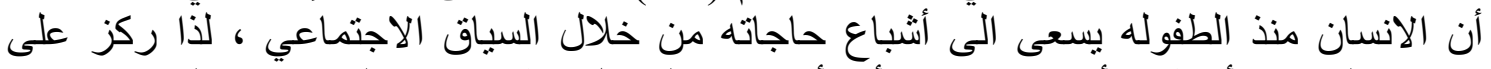

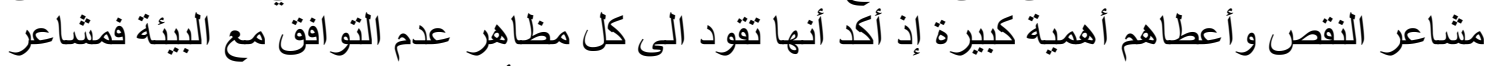

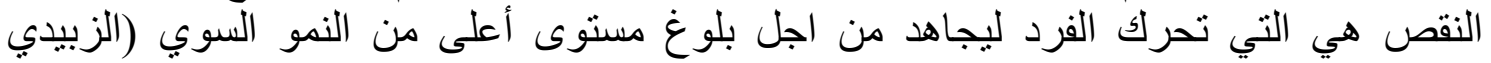

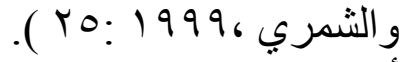
أما ( هورني ) فقد اهتمت بالجانب الإجتماعي للفرد و علاقة الفرد بذاته ،وترى ان العلاقها الحقيقيه

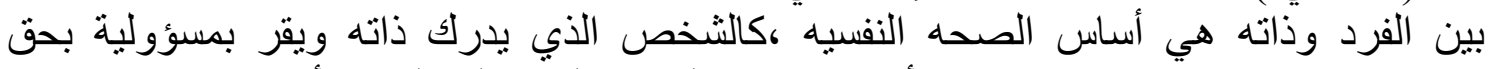

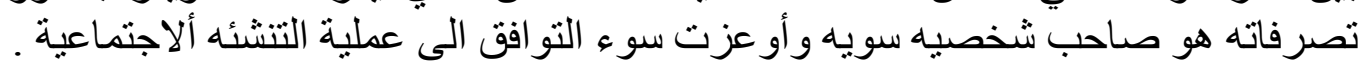

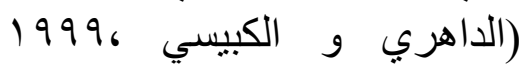

و أثارث هورني أن التوافق الذي يقود الى السواء ، و اللاتوافق الذي يقود الى العصاب يعودان

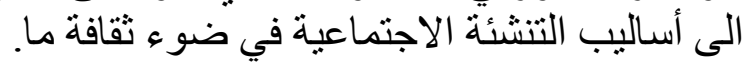

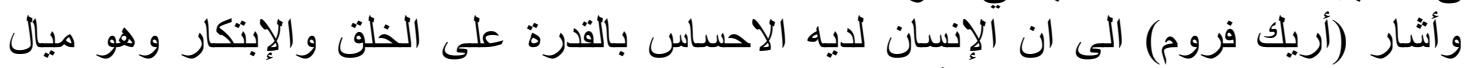

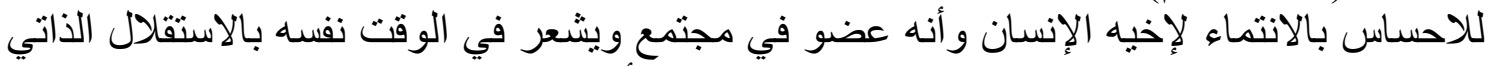

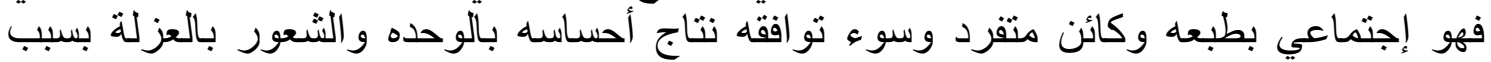

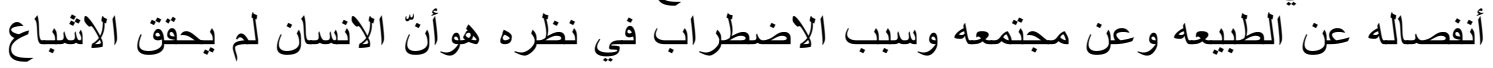

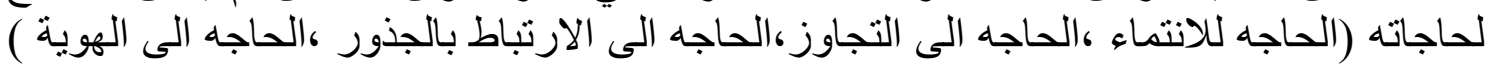

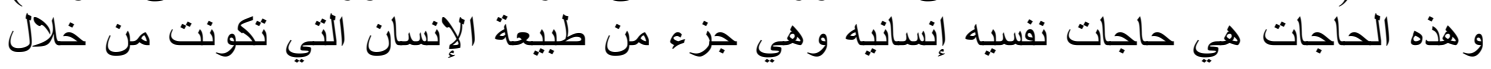

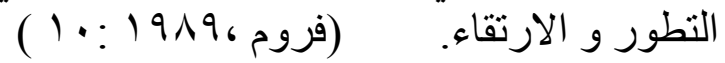

ثانبًا :المدرسة السلوكية :

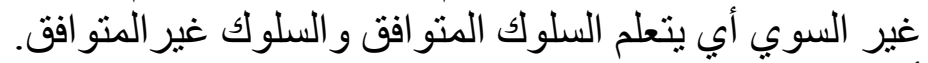

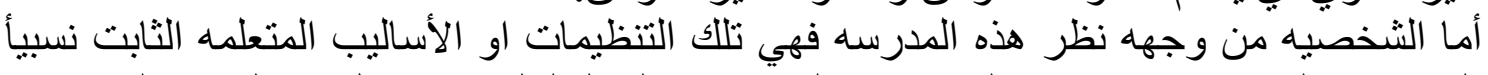
التي تميز الفرد عن غيره من الناس وان الثخص يتعلم السلوك من خلال تفاعله مع البيئه ومع $(1 \cdot 7: 199 V 6$ : ز ألاخرين.

فنجد السلوك لدى ( دو لارد وميلر ) متعلم كما قسم الميز ان الى مجمو عتين وهما :-

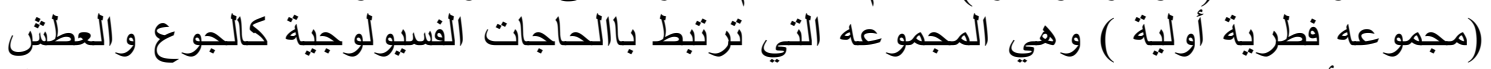

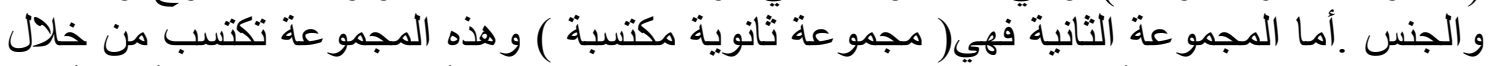

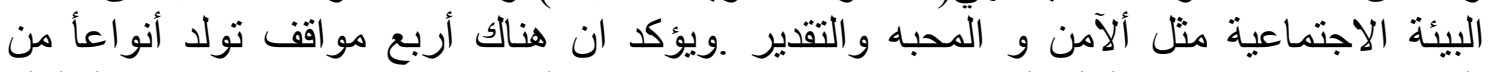

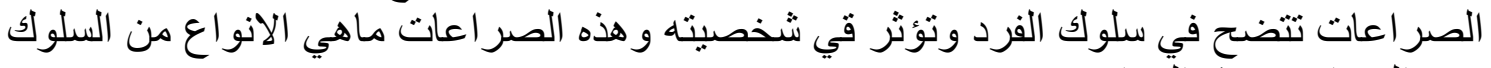

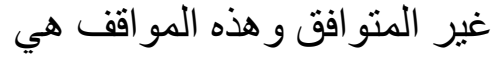
( التغذيه و الفطام ، وضبط وهذه علتية التبول و البراز و التدريب على الجنس و التحكم في أنفعال الغضب 


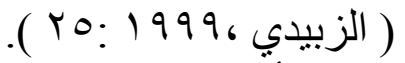

وخلاصة القول أنّ النظرية السلوكيه تفسر المشكلات السلوكية على انها أنماط من الاستجابات

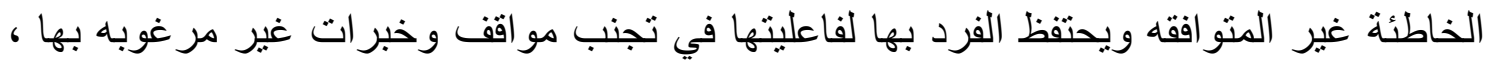

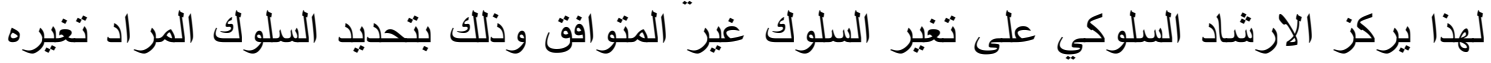

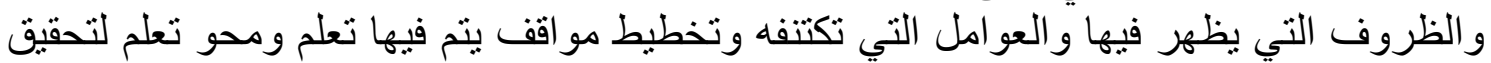

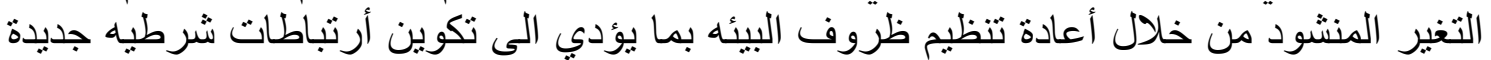

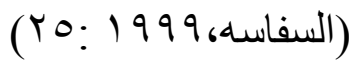
لتحقيق التو افق المطلوب.

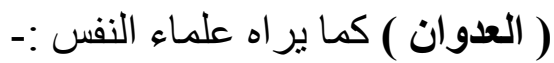

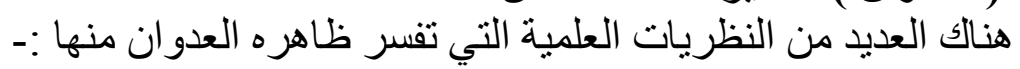

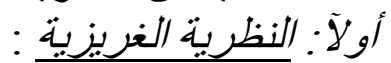

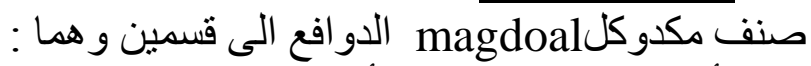

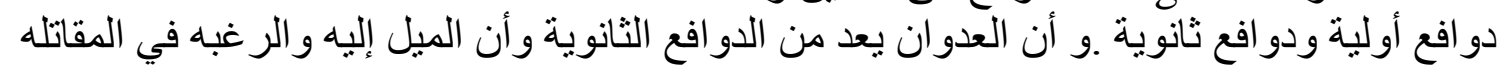

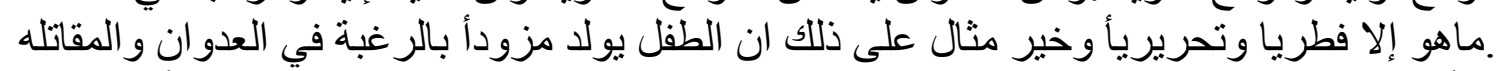

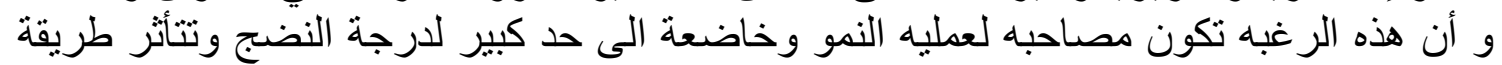

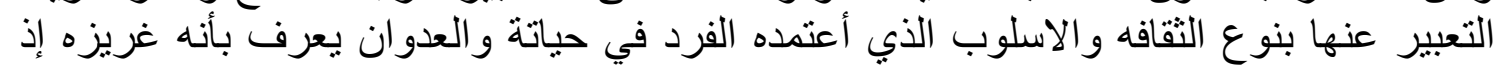

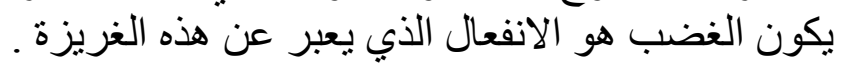

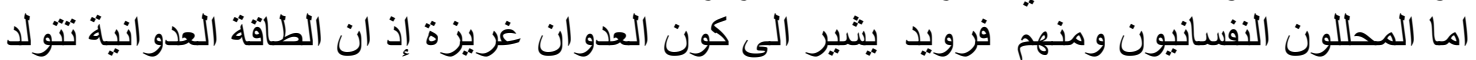

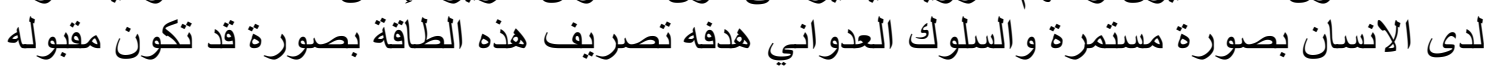
أجنماعبأ ( كالنقاشات الجادة و النشاط الرياض) أو بصورة غير مقبولة (كالاهانات والشجار ) ، أرجع فرويد

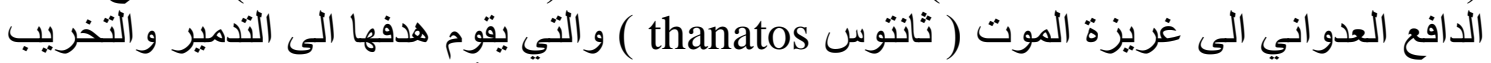

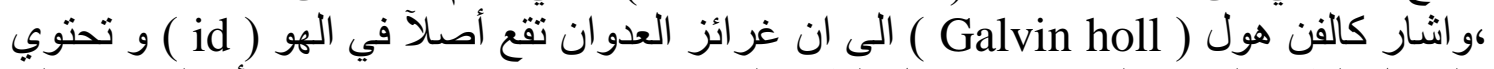

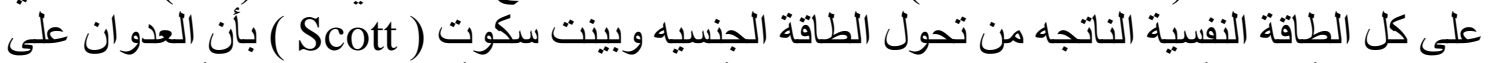

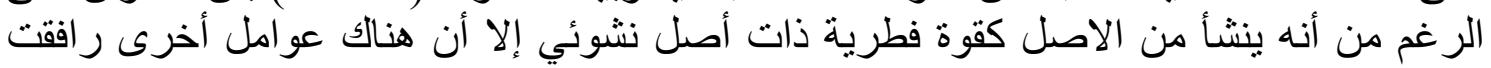

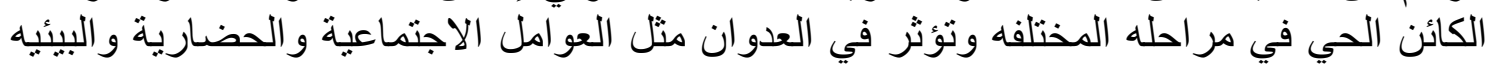

ثنانيأ: النظرية الاحباطية :- تلظرية الإحباط ، العدوان من ان الانسان ليس عدوانيأ بطبعه وانما يصبح كذلك نتيجه للاحباط تنطبق نط:

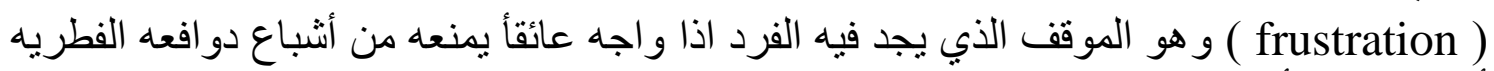

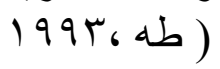

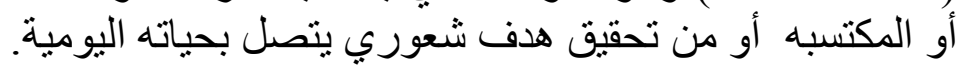

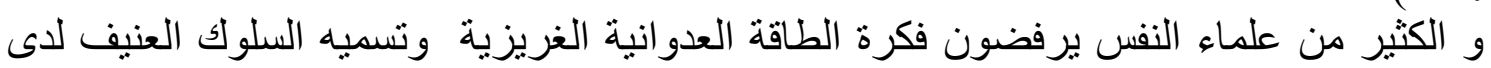

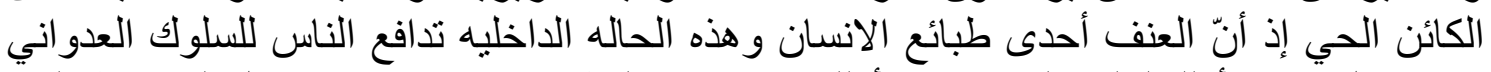

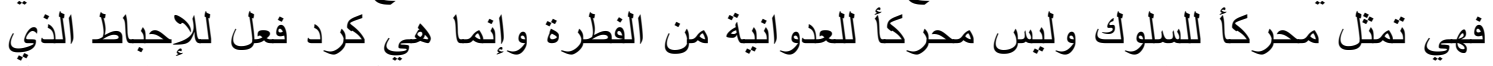

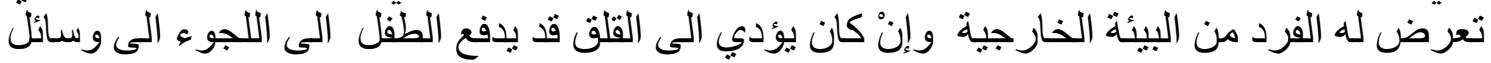

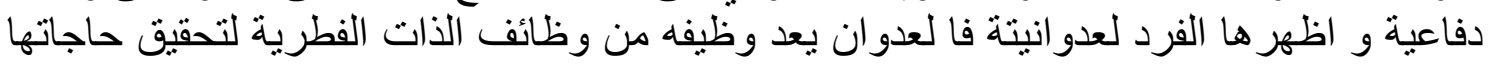


التي تتعلق بحفظ الحياة وتحقيق الامن فالميول العدوانية لاتخرج الى نطاق السلوك و الاداء بتدخل

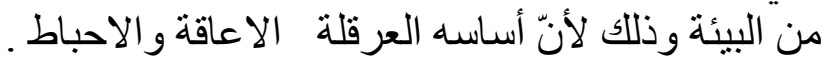

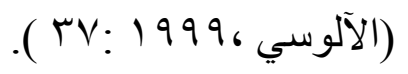

الاراسات التي تناولت التوافق النفسي

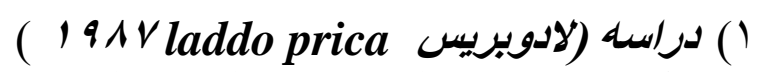

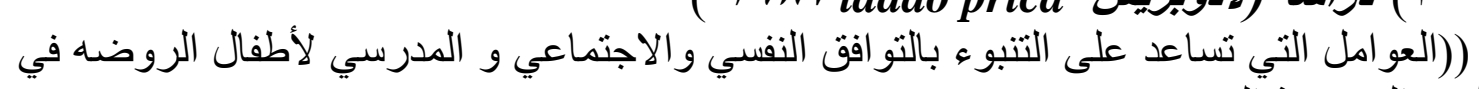

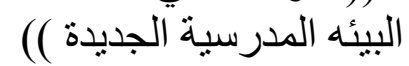

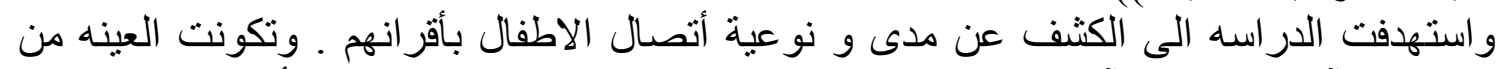

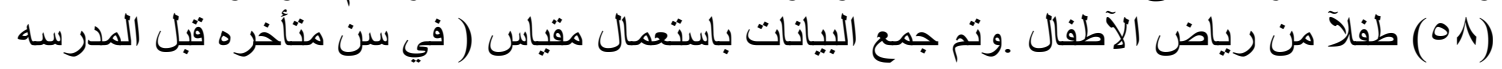

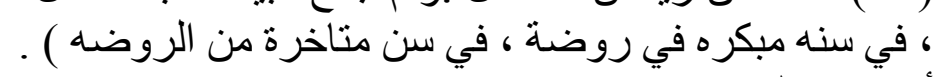

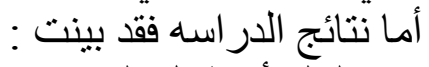

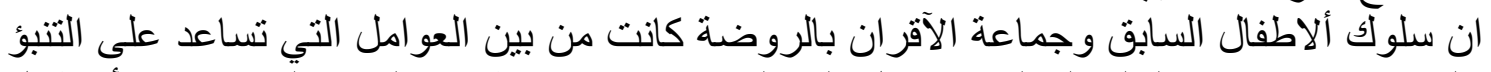

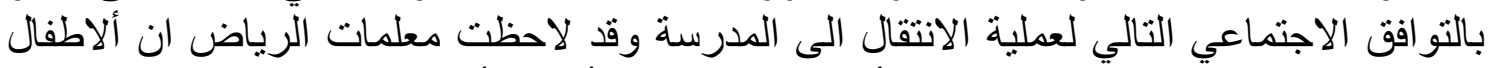

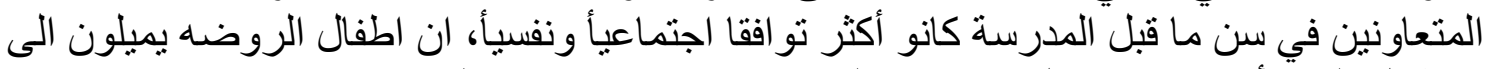

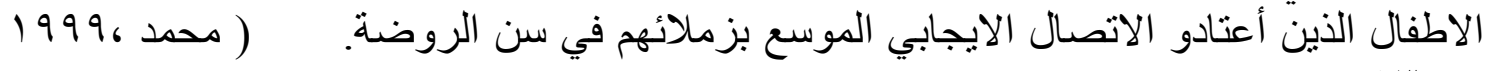

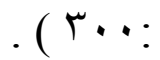

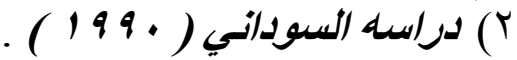

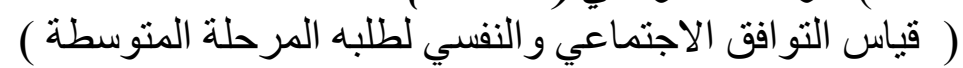

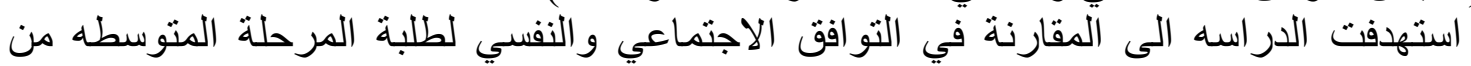

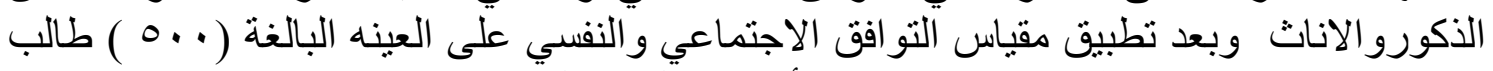

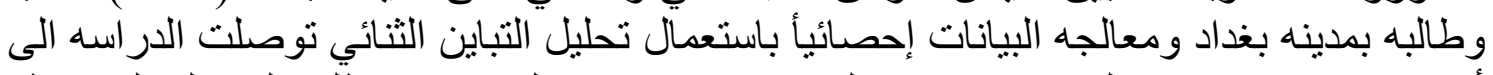

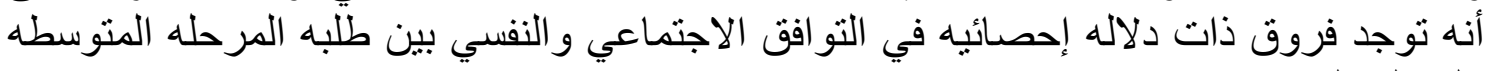

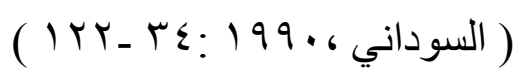
ولصالح الذكور

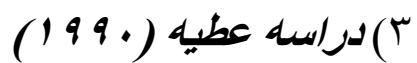

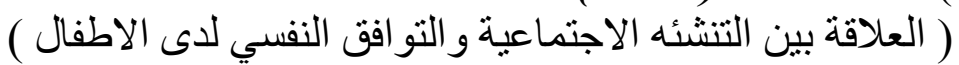

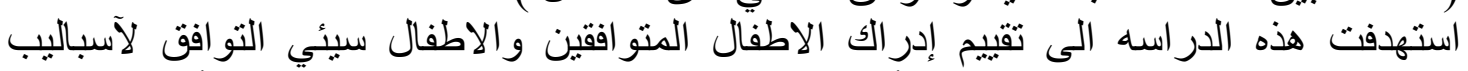

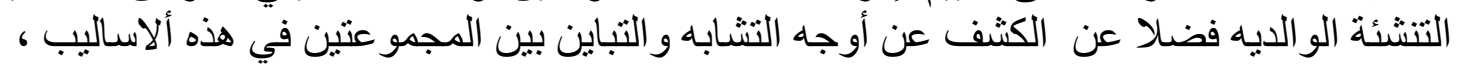

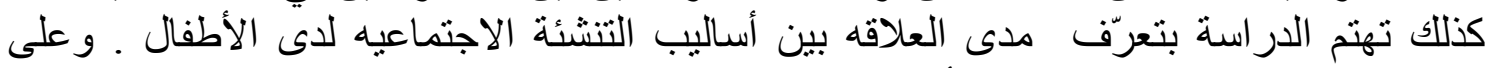

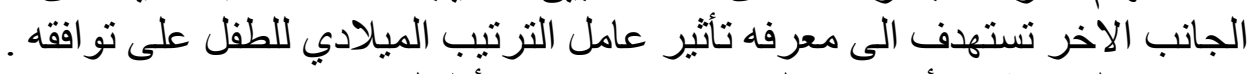

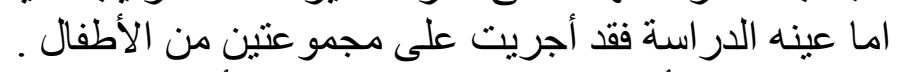

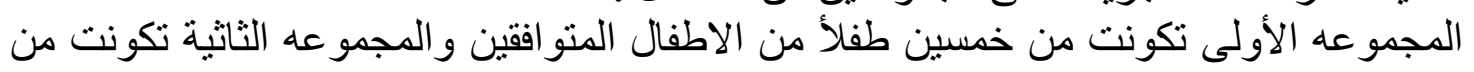
أربعين طفلا سيئ التو افق . تونى

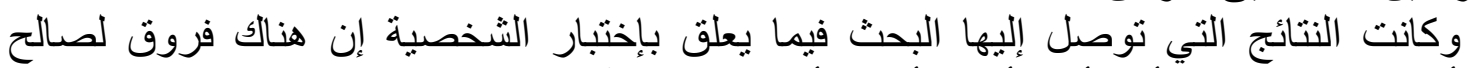

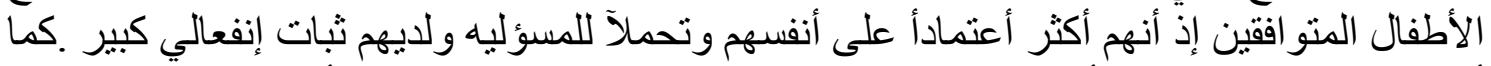

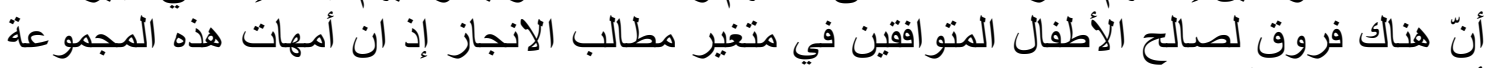

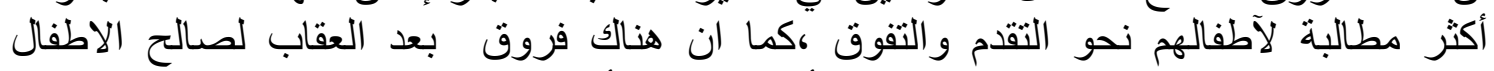

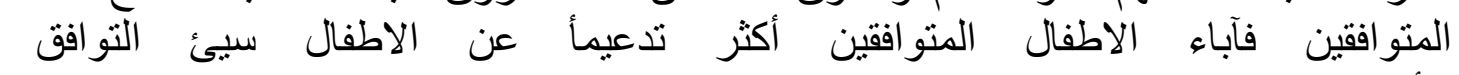

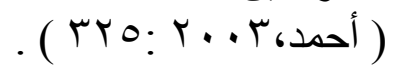




\section{الداسات التي تناولت السلوك العدواني}

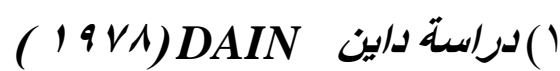

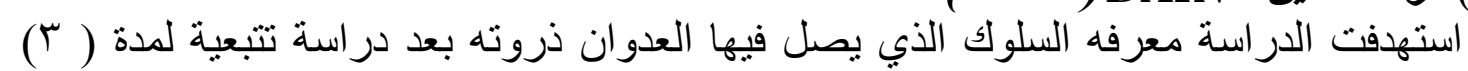

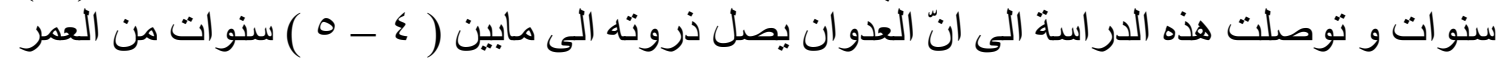

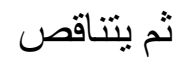

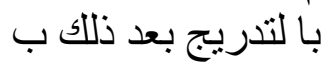

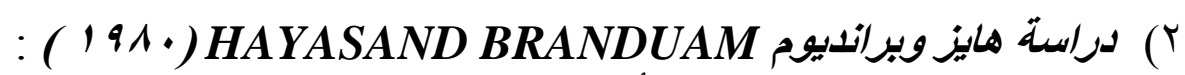

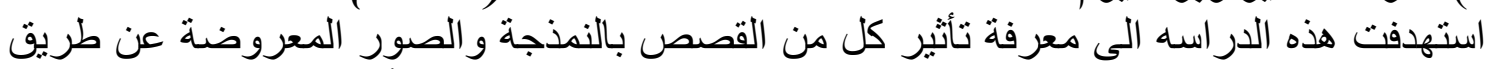

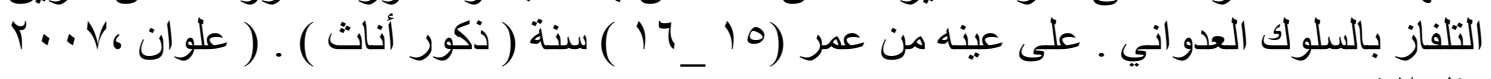

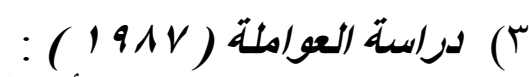

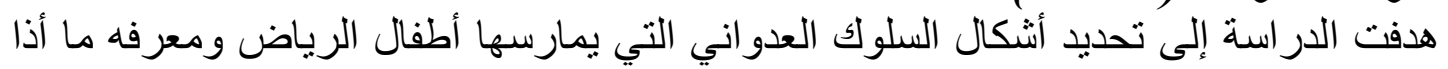

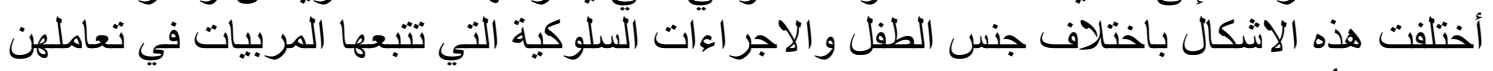

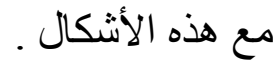

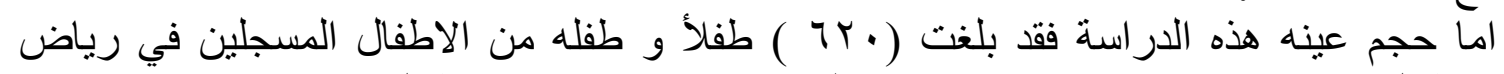

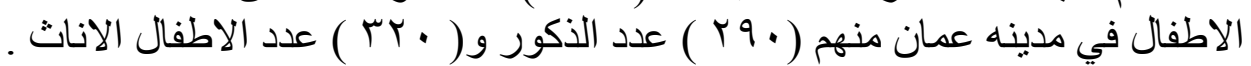

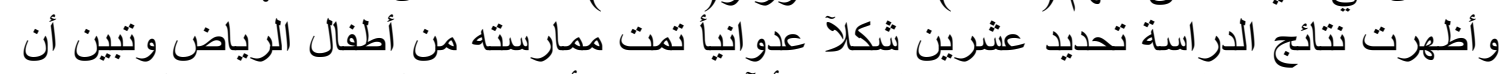

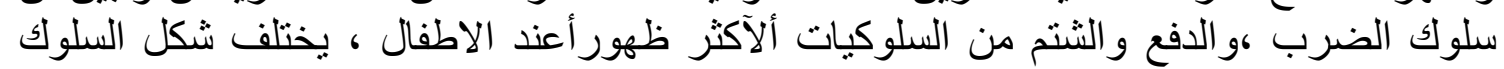

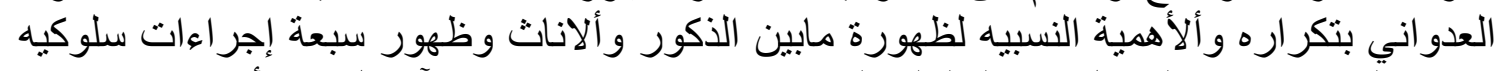

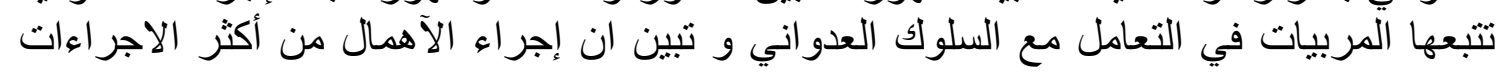
)

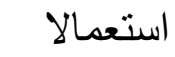

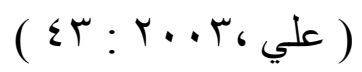

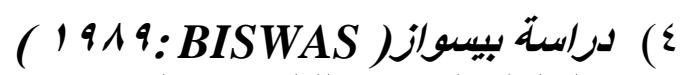

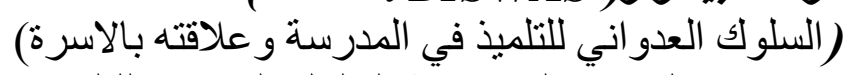

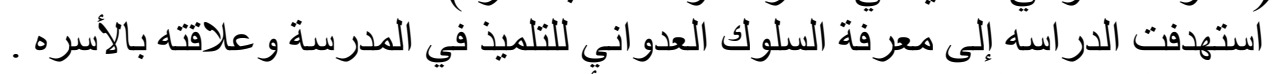

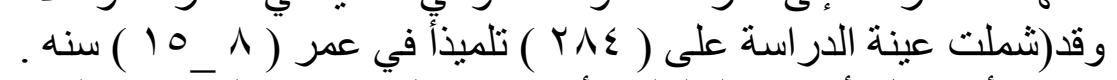

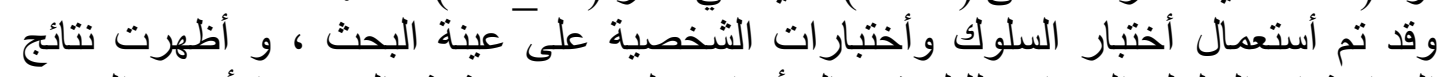

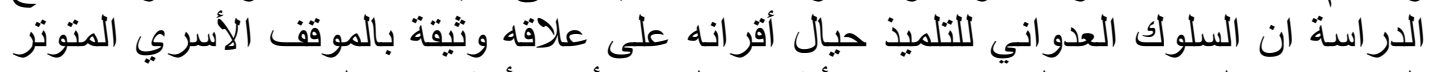
الذي تسوده الخلافات و الصر اعات ، وأنّ هذه العلاقه أثند وأوثق عند الذكور منها عند الاناث الأن

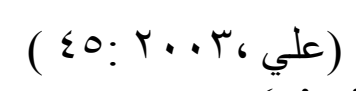

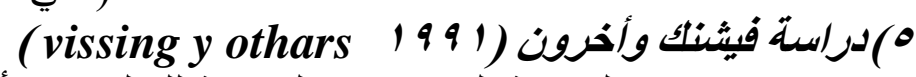

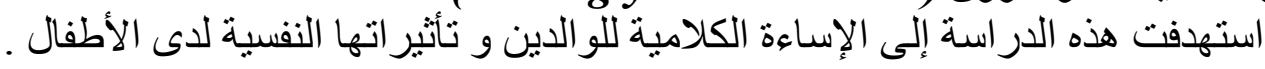

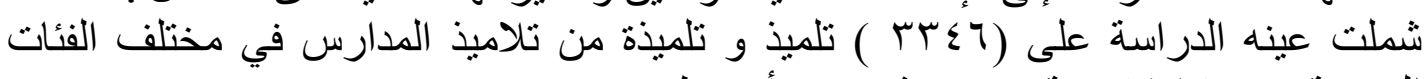
العمرية دون ( 11 ) سنة ممن يعيشون في أسر طبيعيه . 


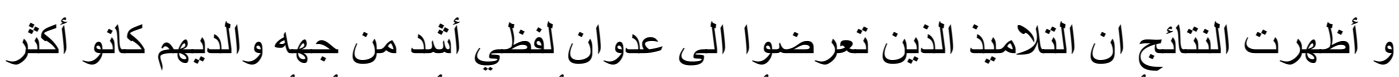

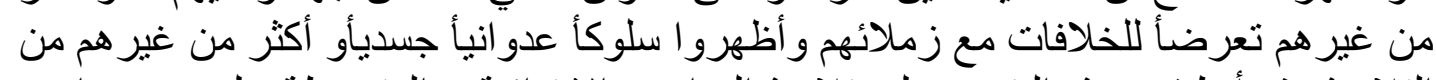
التلاميذ وقد أنطبقت هذه النتيجه على تلاميذ الددارس الابتدائية و المتوسطة علئه على حد سواء و ون ( $)$ لكلا الجنسين . منهجية البحث و اجر اعتة

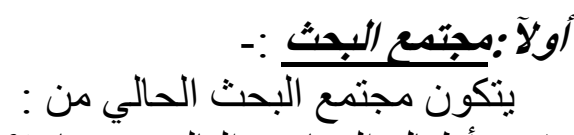

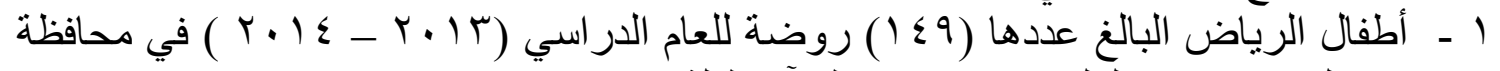

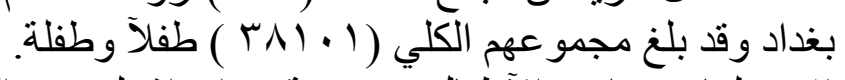

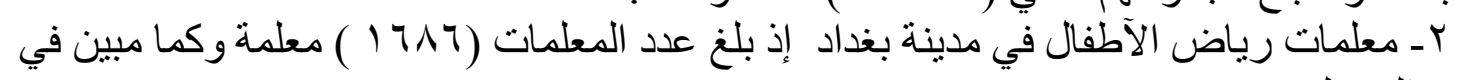

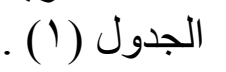

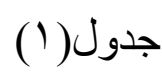

\begin{tabular}{|c|c|c|c|c|c|}
\hline \multirow[t]{2}{*}{ عدد المعلمات } & \multicolumn{2}{|c|}{ عدد الاطفال } & \multirow[t]{2}{*}{ عدد الرياض } & \multirow{2}{*}{ مديريات الرياض } & \multirow[t]{2}{*}{ المحافظة } \\
\hline & الاناث & الذكور & & & \\
\hline Y97 & TOV. & $r \wedge \cdot \varepsilon$ & rq & كرخ أولى & \multirow{8}{*}{ بغداد } \\
\hline (q) & . צחץ. & $r \leqslant \vee q$ & $r q$ & كر خ ثنانية & \\
\hline سגו & $r \leq Y T$ & rvo & 17 & كرخ ثالثة & \\
\hline$V V \cdot$ & NTOT & $170 \wedge$ & $V \varepsilon$ & المجموع & \\
\hline$\varepsilon \leqslant 0$ & हाV. & $\varepsilon 0 . r$ & rA & رصافة أولى & \\
\hline$\varepsilon \cdot \varepsilon$ & $\leqslant 9 \cdot \varepsilon$ & or 90 & $\leqslant r$ & رصافة ثانية & \\
\hline $7 V$ & $q r$. & 1.90 & 0 & رصافة ثالثة & \\
\hline 917 & $1.19 \varepsilon$ & 1.199 & Vo & المجموع & \\
\hline
\end{tabular}

* تم الحصول على البيانات من المديريات العامة للتربية قسم التخطيط التربوي .

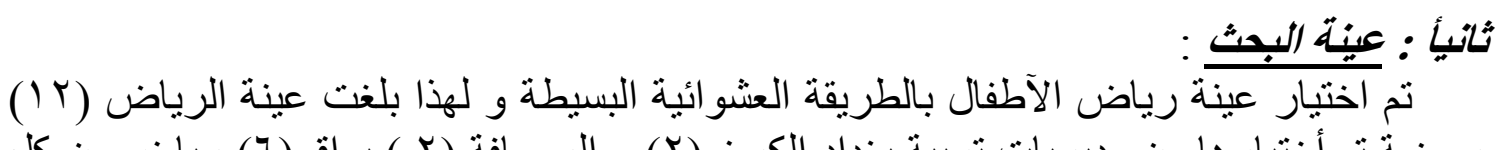

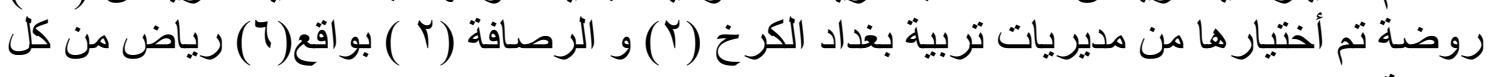

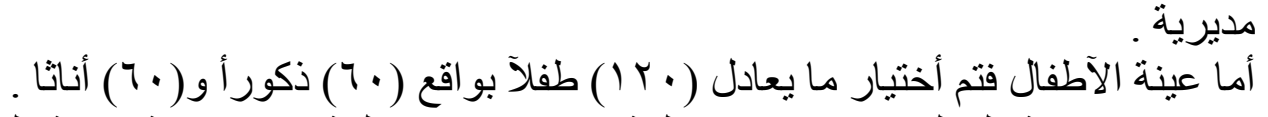

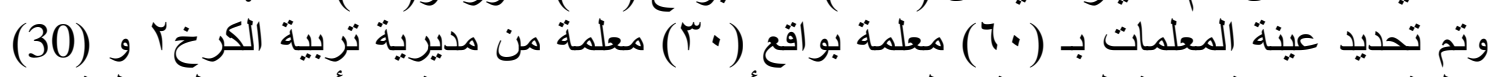

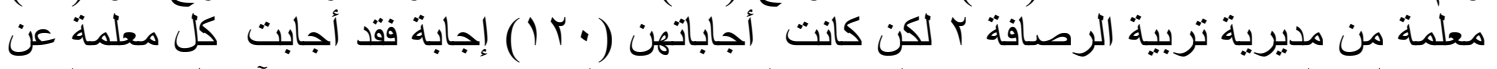

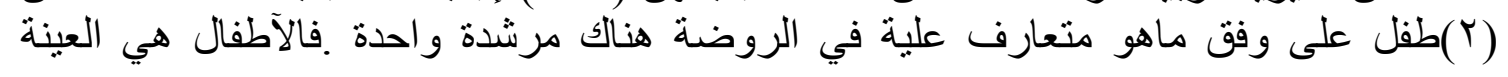


المدروسة التي ستجيب عنها المعلمات إذ لا يستطيع الاطفال الأجابة عن حالتهم و أنفسهم وكما

جدول (r) (ب)

موضح في الجدول (Y).

توزيع عينة رياض الاطفال و عينة ألاطفال و المعلمات حسب المديريتين

\begin{tabular}{|c|c|c|c|c|c|c|}
\hline عبينة & المجموع & الاطاثفال & 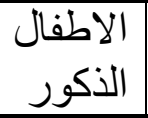 & عدد & المديريات & $ت$ \\
\hline$r$. & 7. & $r$. & $\Gamma$. & 7 & كرخ أولى & -1 \\
\hline$r$. & 7. & r. & $r$. & 7 & رصافة ثانية & $-Y$ \\
\hline 7. & IT. & 7. & 7. & $1 T$ & المجموع & \\
\hline
\end{tabular}

ثأثأُ أدوات البحث

أـ مقياس التوافت التق التفسي:

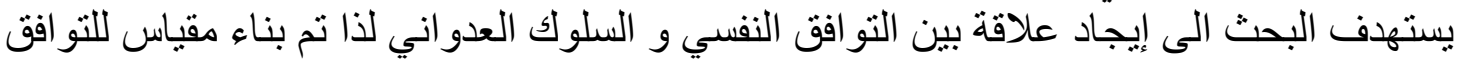

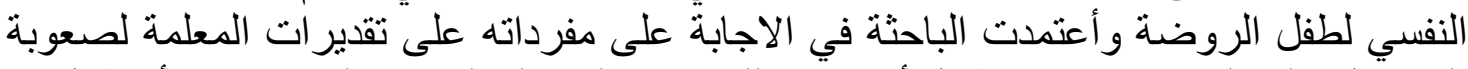

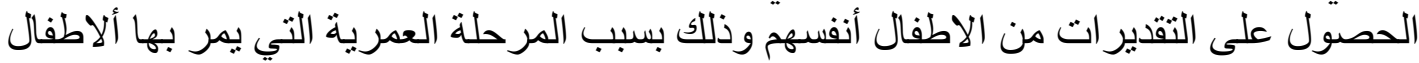

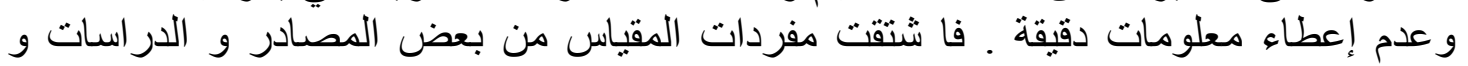

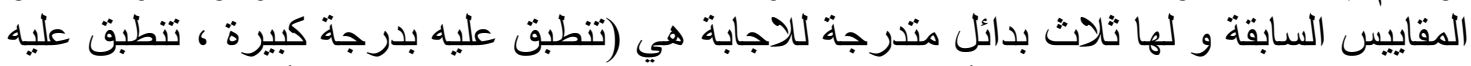

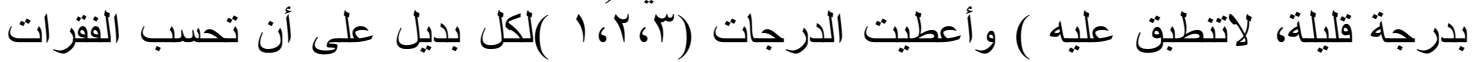

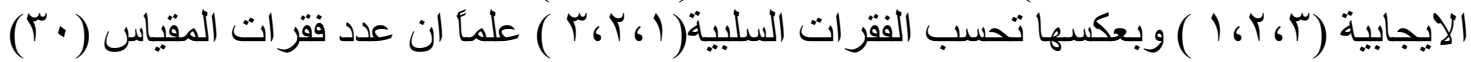
فقرة .

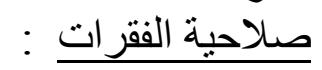
عرض المقياس بصورتة الاولية على مجموعة من الخبراء المتخصصين في العلوم التربوية

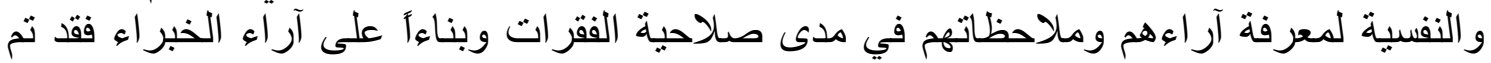

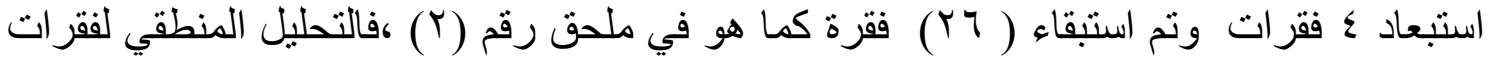

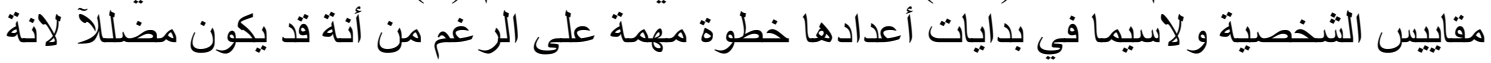

1910: عبد الخالق )

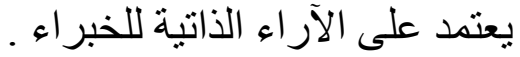

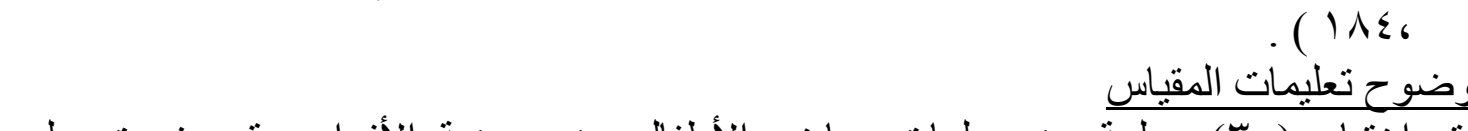

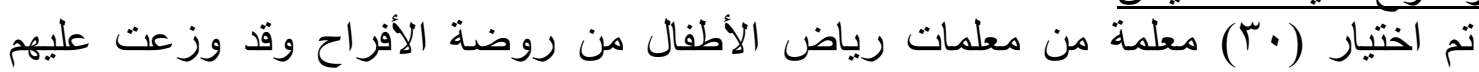

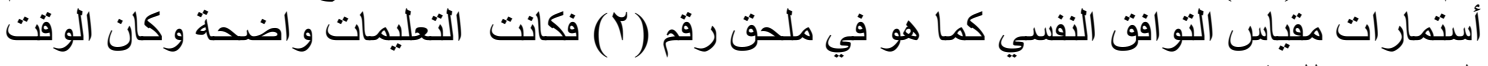

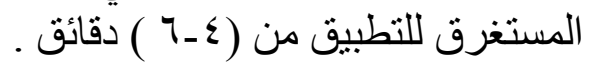

يتكون المقياس من متدرج ثناثي (تنطبق عليً دائمأ ، تنطبق عليَ أحيانأ ،لاتنطبق عليَ أبدأ)

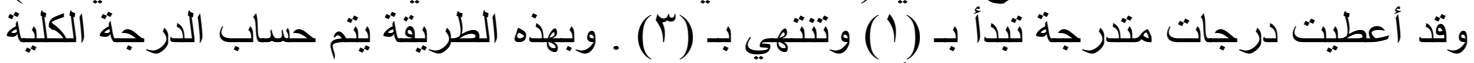

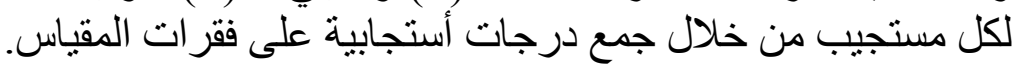
صدق المقياس : ونعن من ونعني بالصدق : هوصلانية الأداة في قياس الجانب المقصود قياسه وهو الاختبار على تأدية

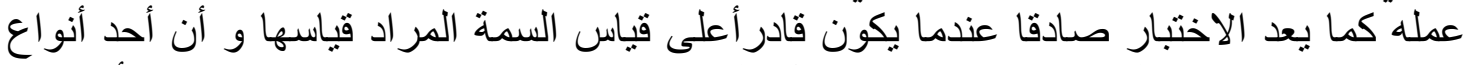

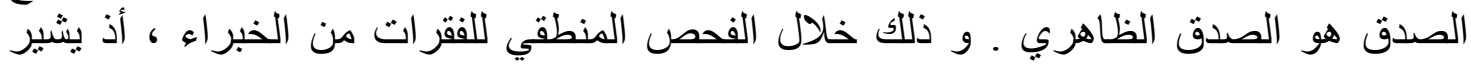




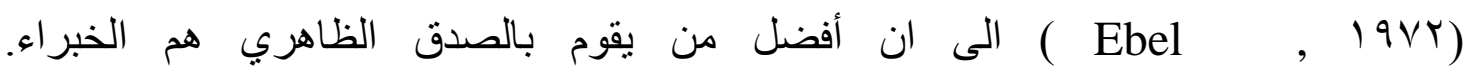

تُبقت المقياس :

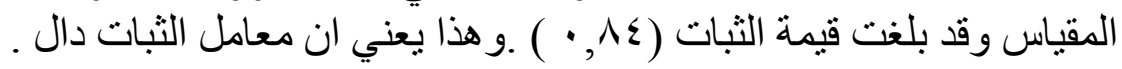

ب _ مقياس السلوك العدوانى تئي

تبنت الباحثة ( مقياس علي )* الذي قامت بينائه وكان البحث مخصص لأطفال المرحلة الأبتدائية

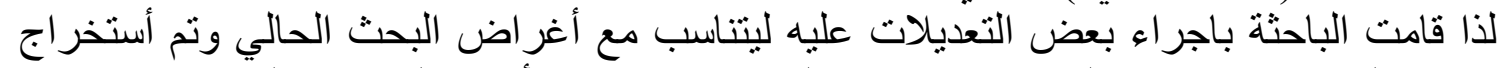

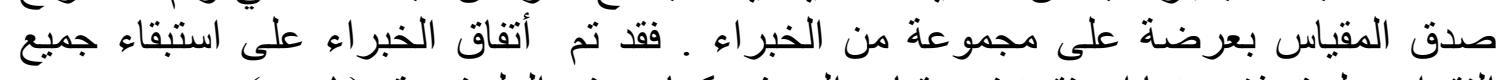

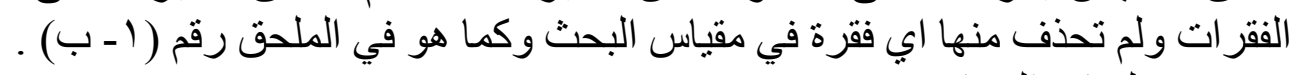

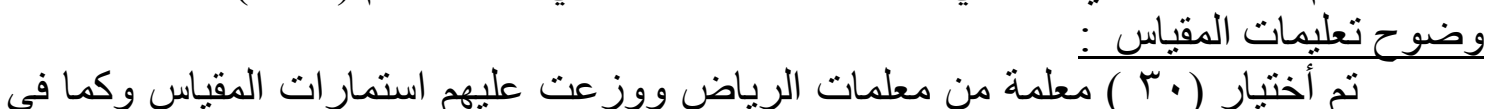

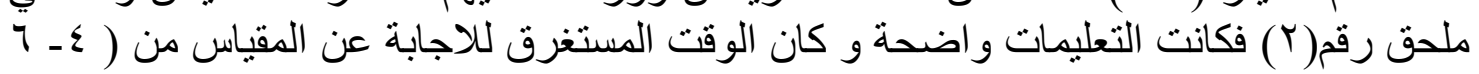
) دقائق .

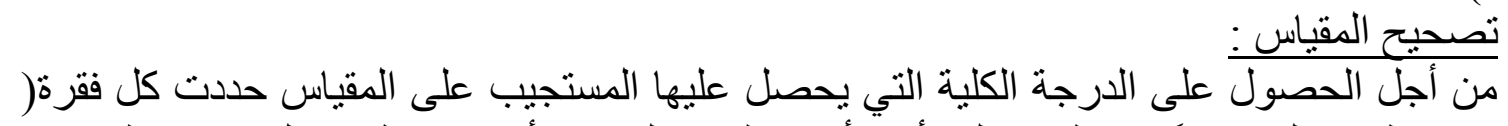

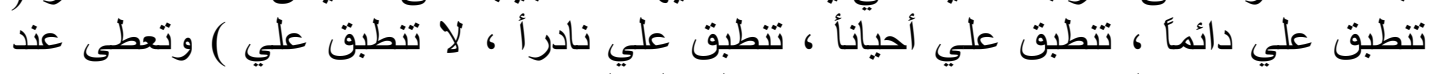

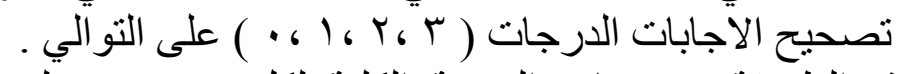

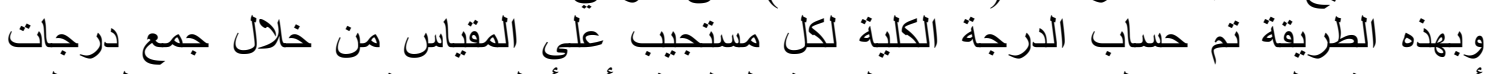

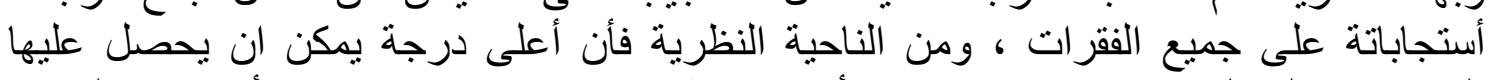

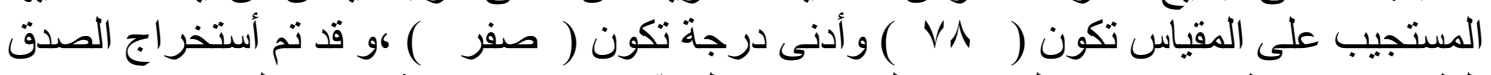

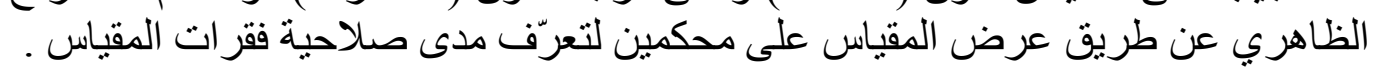

تثبات التجزئة النصفية: التجزئة النصفية من العينة نفسها ومن التطبيق الأول باستخدام معادلة

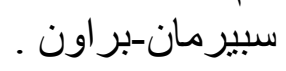

رابعا : الوسائل الاحصائية :-

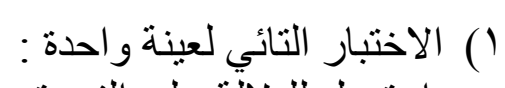

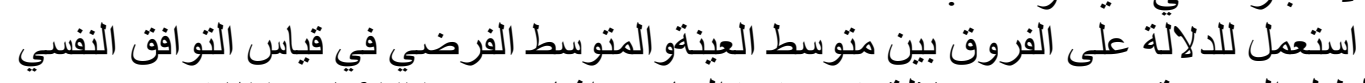

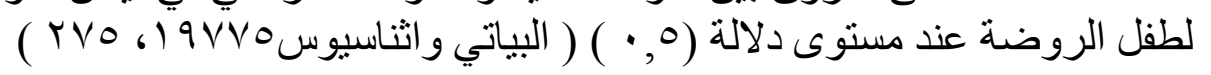

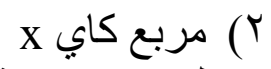

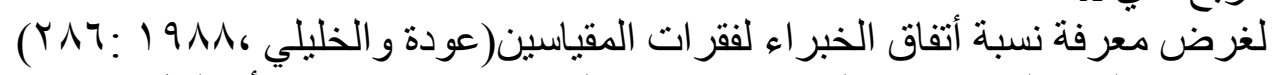

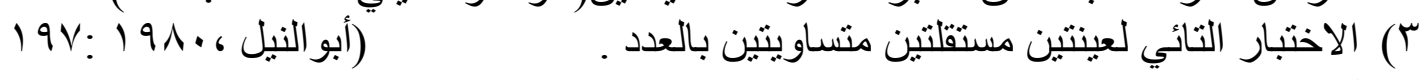




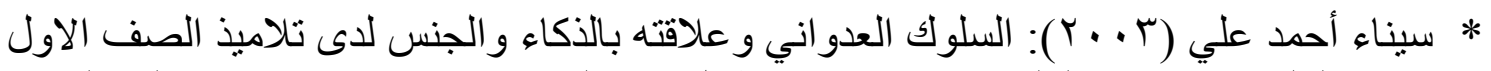

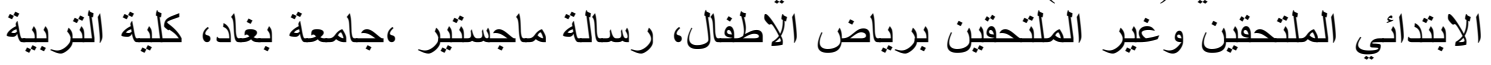

\section{عرض النتائج و مناقثتها}

\section{الفرضية الصفرية الأولى :}

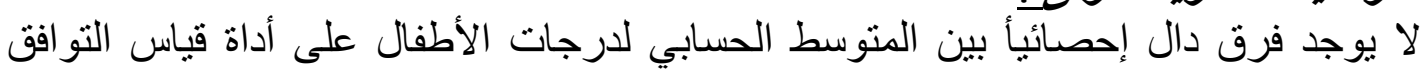

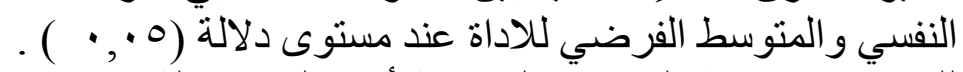

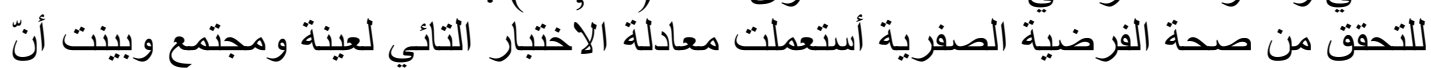
هناك تو افق نفسي للاطفال عينة البحث إذ بلغت القيمة التائية المحسوبة ( من القيمة

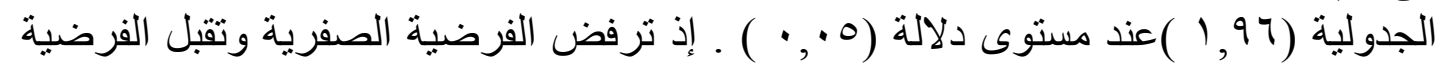

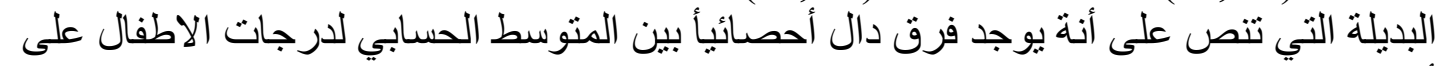

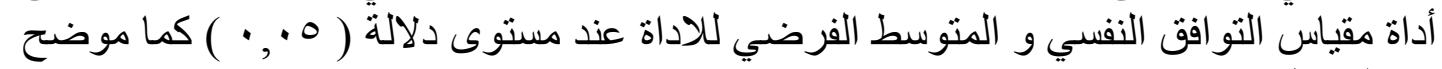

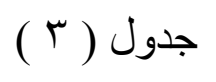

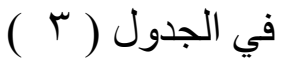

القيم الاحصائية للفرضية الصفرية الاولى

\begin{tabular}{|c|c|c|c|c|c|}
\hline & القيمة التائية & الانحر اف & الوسط & الوسط & \\
\hline الجدولية & المحسوبة & المعياري & الفرضي & الحسابي & \\
\hline 1.97 & $0.2 \lambda$ & $11 . \varepsilon$ & or & ov. $Y$ & IY. \\
\hline
\end{tabular}

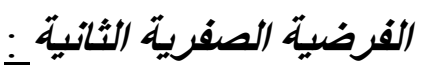

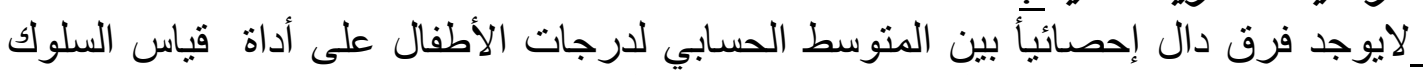

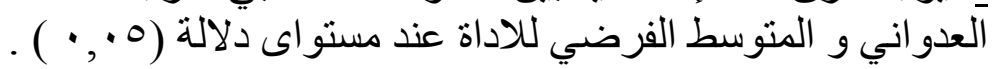

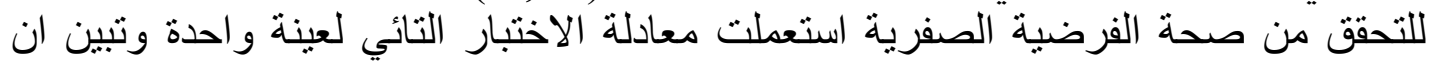

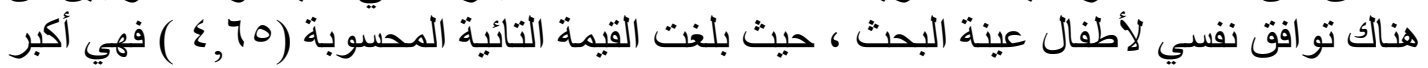

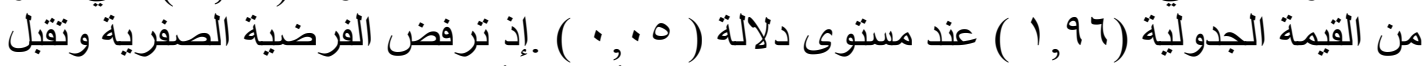

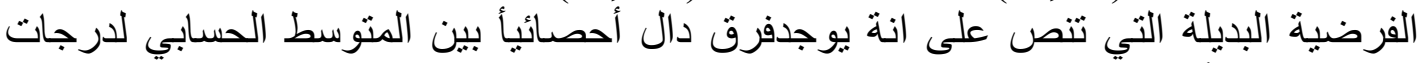

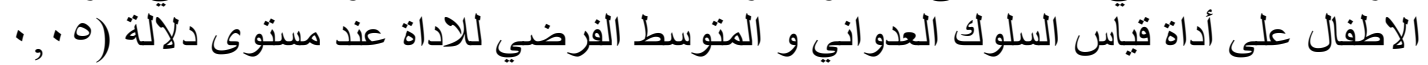
) كما هو موضح في الجدول ( ع ألين ) ) 


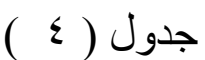

القيم الاحصائية للفرضية الصفرية الثانية

\begin{tabular}{|c|c|c|c|c|c|}
\hline & القيمة التائيخا & الانحر اف & الوسط & الوسط & ينة \\
\hline الجدولية & الدحسوبة & المعياري & الفرضي & الحسابي & \\
\hline 1.97 & $\varepsilon .70$ & $1 \leq .1 \pi$ & rq & $v_{1} . .$. & \\
\hline
\end{tabular}

\section{الفرضية الصفرية الثالثة:}

لاتوجد علاقة دالة إحصائيأبين درجات الاطفال على على أداة قياس التوافق النفسي و درجات

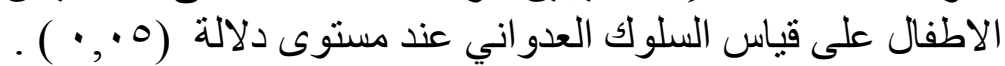

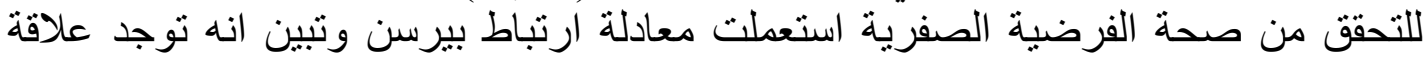

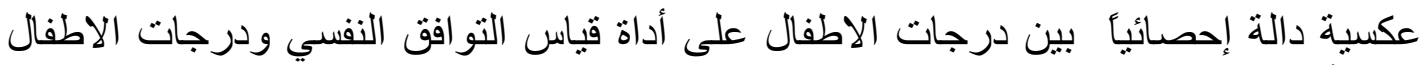

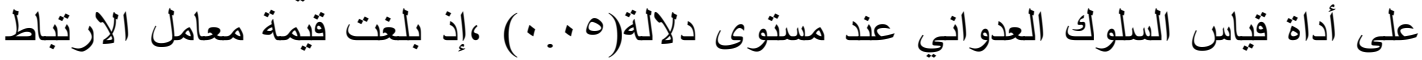

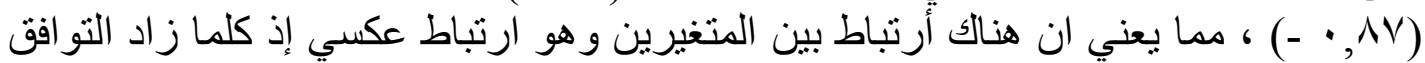

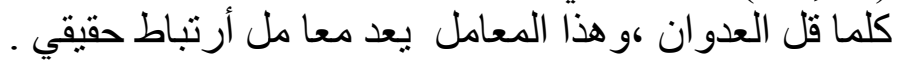

\section{الفرضية الصفرية الرابعة :}

لايوجد فرق دال إحصائياً بين المتوسط الحسابي لدرجات الدات الاطفال الذكور و المتوسط الحسابي

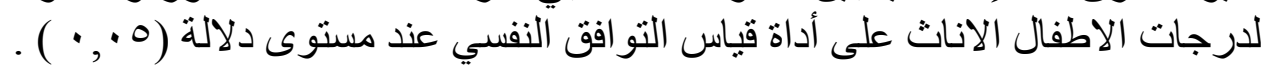

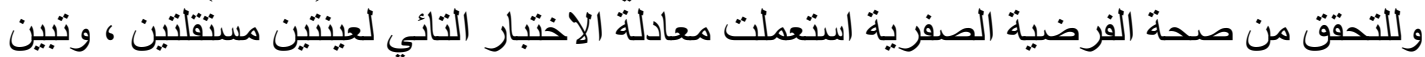

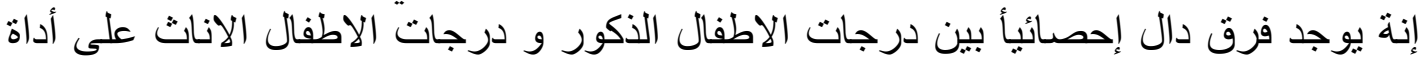

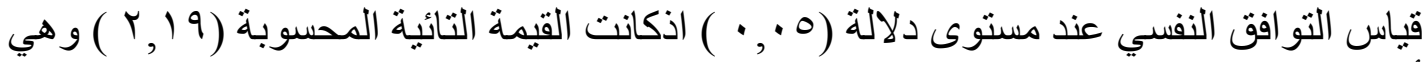

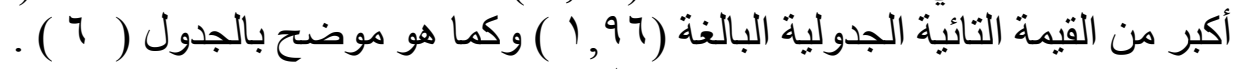

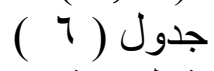

قيمة الاختبار التائي للفرضية الصفرية الرابعة

\begin{tabular}{|c|c|c|c|c|}
\hline & القيمة التائي & الانحر اف & الوسط & \\
\hline الجدولية & المحسوبة & المعياري & الحسابي & س \\
\hline \multirow{2}{*}{1.97} & \multirow{2}{*}{ r. 19} & $\mid \cdot .71$ & $00 . Y^{\mu}$ & ذكور \\
\hline & & $1 \leq . \Gamma \wedge$ & $0 \wedge . \wedge$ & إناث \\
\hline
\end{tabular}

وبهذه النتيجة نجد عينة أطفال الرياض من الذكور و الاناث يتسمون بالتوافق النفسي فاذا نم

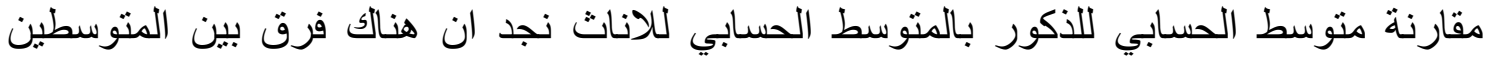

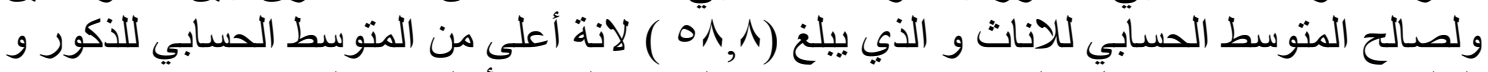

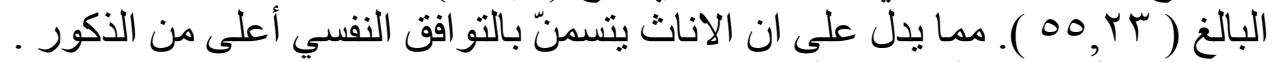

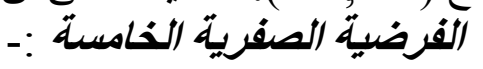
لايوجد فرق دال إحصائياً بين المنوسط الحسابي لإني لدرجات الاطفال الذكور و المتوسط الحسابي

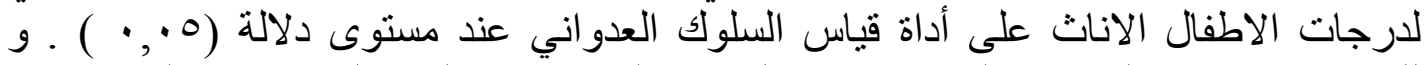
للتحقق من صحة الفرضية الصفرية استعملت معادلة الاختبار التائي لعينتين مستقلتنين ، تبين 
إنهُ لا يوجد فرق دال احصائياً بين درجات الاطفال الذكور ودرجات الاطفال الاناث على أداة

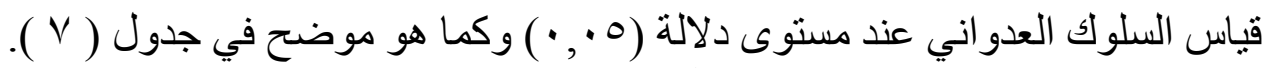

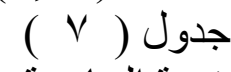

قيمة الاختبار التائي للفرضية الصفرية الخامسة

\begin{tabular}{|c|c|c|c|c|}
\hline \multicolumn{2}{|c|}{ القيمة التائية } & \multirow{2}{*}{ الانحياري اف } & \multirow{2}{*}{ الحسابي } & \multirow[b]{2}{*}{ الجنس } \\
\hline الجدولية & المحسوبة & & & \\
\hline \multirow{2}{*}{1.97} & \multirow{2}{*}{1.70} & $1 \varepsilon .7 V$ & $V Y . V Y$ & ذكور \\
\hline & & $|r . v|$ & 79.71 & كاث \\
\hline
\end{tabular}

وبهذه النتيجة نجد عينة أطفال الرياض من الذكور و الاناث ليس لديهم سلوك عدواني فاذا تم

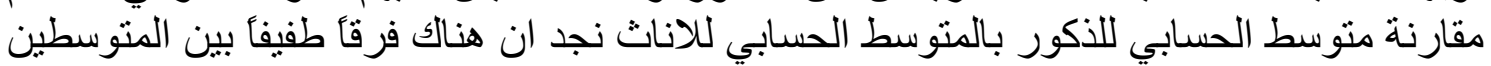

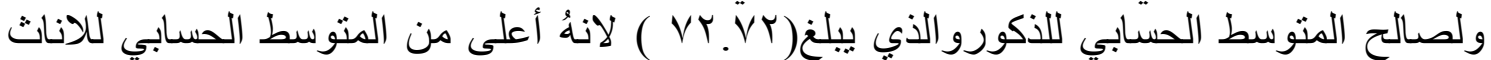

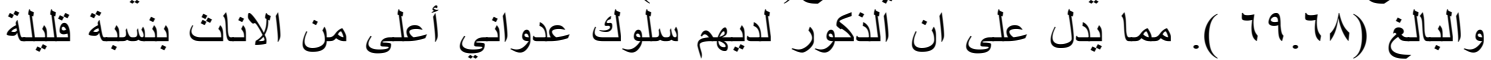
جدألكن لم تصل القيمة المحسوبةالى القيمة الجدولية وبذلك تقبل الفيل الفرضية الصفرية.

\section{الفرضية الصفرية السادسة : الحفانية}

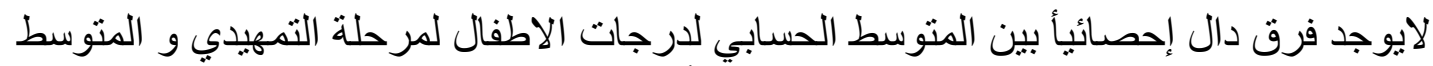

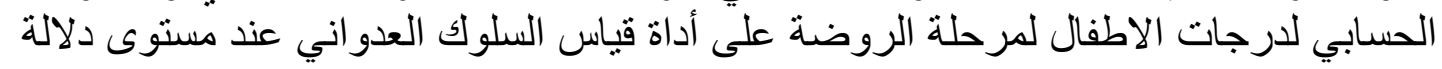
(0,

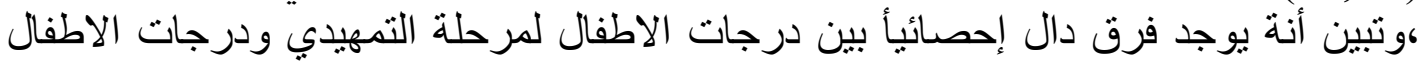

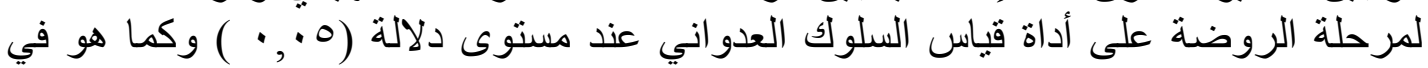

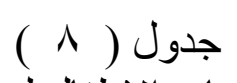

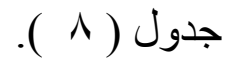

قيمة الاختبار التائي لدرجات الاطفال لمرلة ملة الروضة و التمهيدي

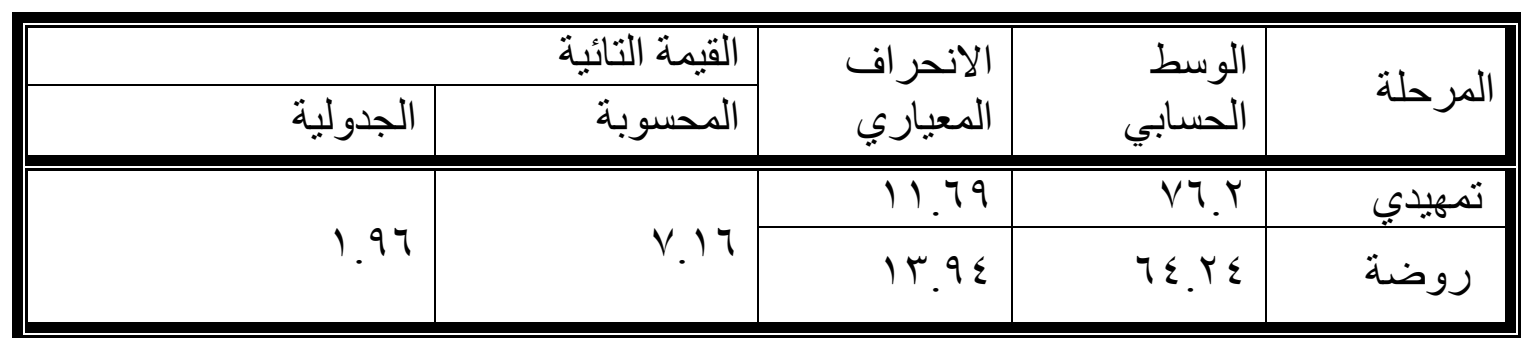

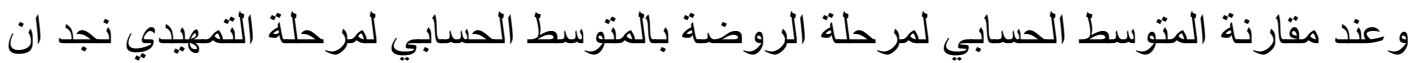

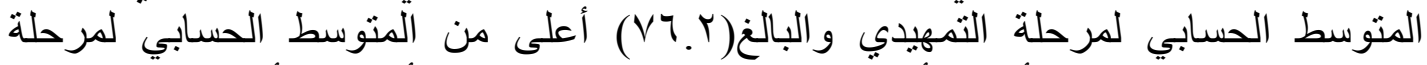

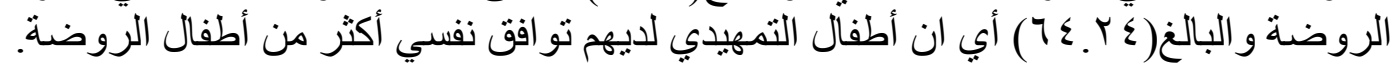

\section{الفرضية الصفرية السابعة_:-}

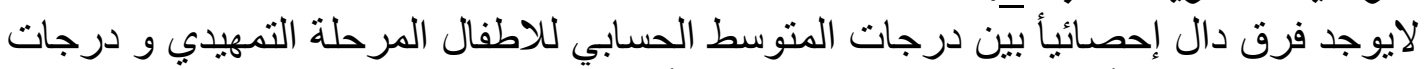

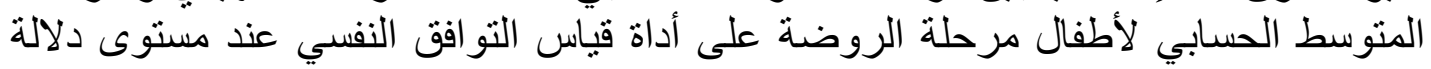

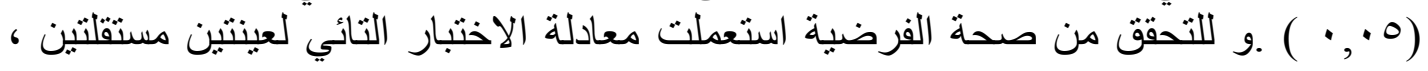


وتبين أنهُ يوجد فرق دال إحصائياً بين درجات الاطفال لمرحلة التمهيدي و درجات الاطفال

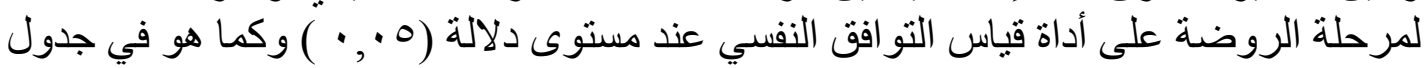

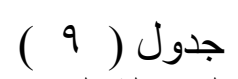

قيمة الاختبار التائي لدرجات الاطفال لمرحلة الروضة ول التمهيدي

\begin{tabular}{|c|c|c|c|c|}
\hline \multicolumn{2}{|r|}{ القيمة التائية } & \multirow{2}{*}{ الانحر افياري } & \multirow{2}{*}{ الحسطابي } & \multirow{2}{*}{ المرحلة } \\
\hline الجدولية & المحسوبة & & & \\
\hline \multirow{2}{*}{1.97} & \multirow{2}{*}{ דצr. } & $1 \wedge . \wedge \varepsilon$ & 70.71 & تمهيدي \\
\hline & & 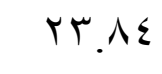 & 09.119 & روضة \\
\hline
\end{tabular}

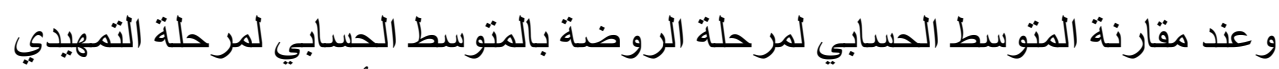

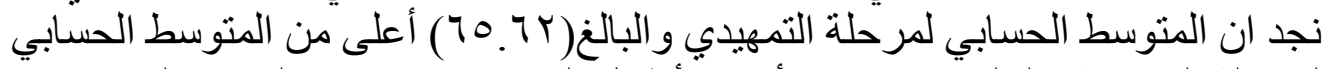

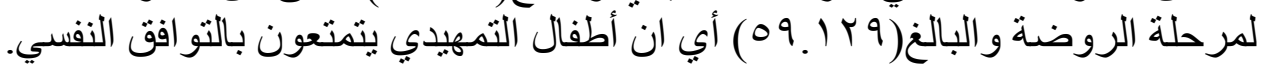

\section{مناقثة نتائج البحث وتفسيرها}

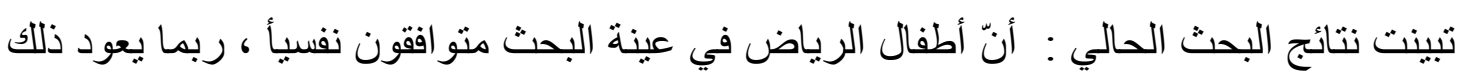

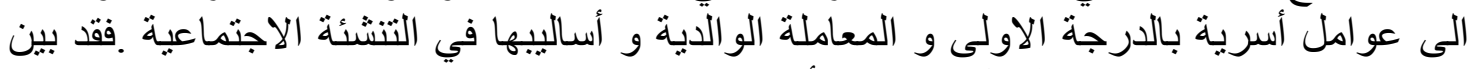

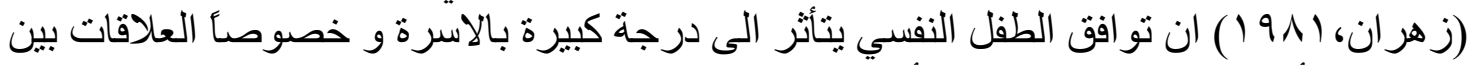

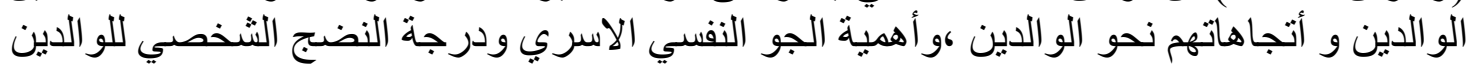

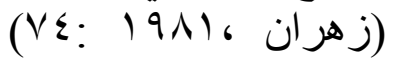

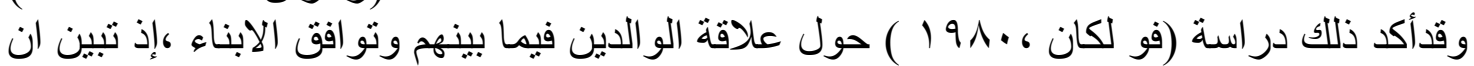

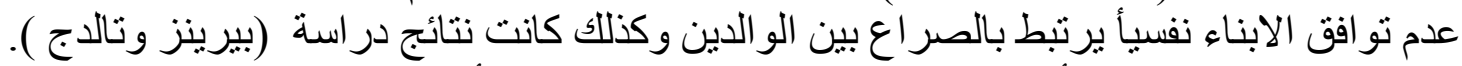

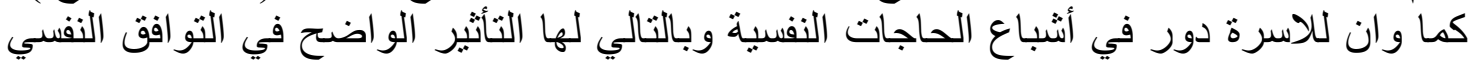

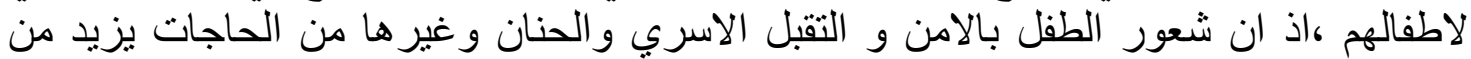

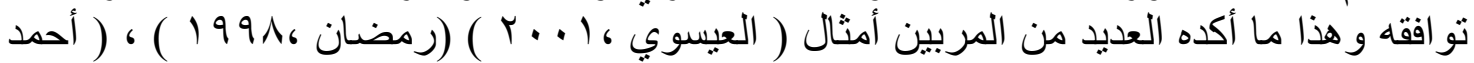

وان رياض الاطفال تؤثر هي الاخرى في التوافق النفسي الناجح للطفل من خلال إتصالة

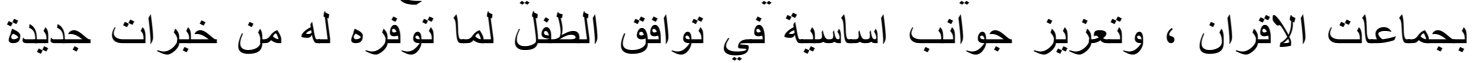

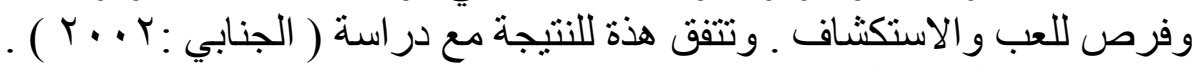

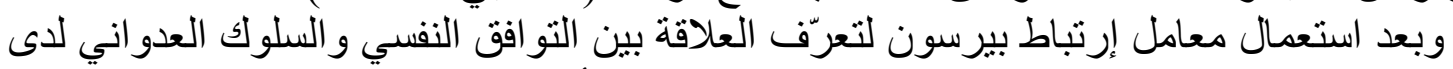

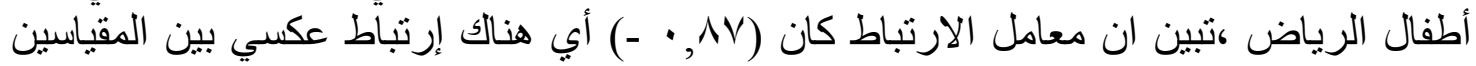

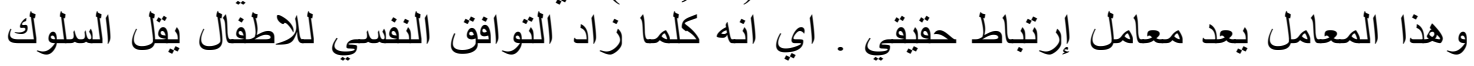

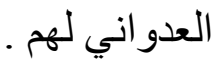
وكماً توصل البحث الى أن اطفال الرياض من الذكور يتصفون بالسلوك العدواني ، وهذا بدل

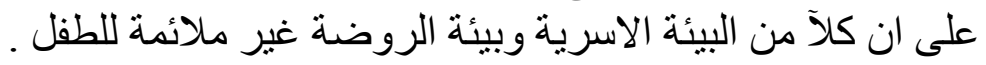


فدور الروضة هنا غير فعال إذ لاتؤدي دورها الهادف في توجية السلوك توجيهأ صحيحأ مما يؤدي التوني

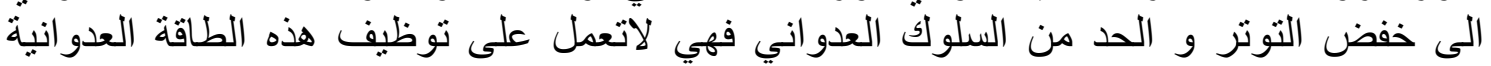

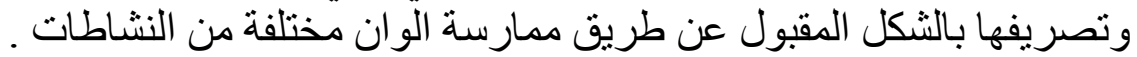

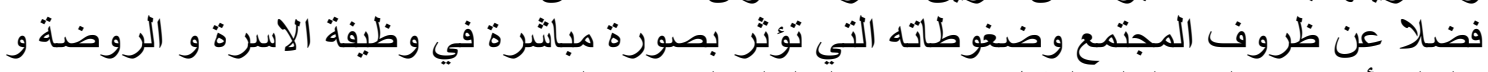

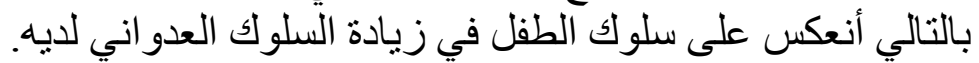

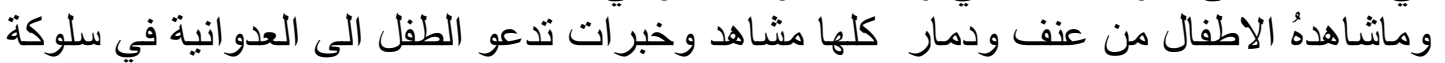

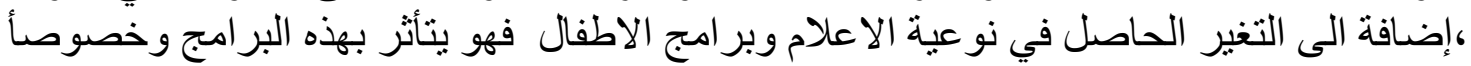
في هذه المرحلة العمرية فهي تدخل ضمن خبر اتة فكلها عو امل ساعدت الطفل في ان ينشئ بشكل فالطفل مليء بلئ بالطاقة والحيوية والنشاط التي لايمكن كبتها وكما كان جو كل من الاسرة و

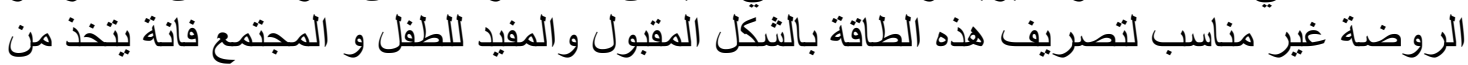

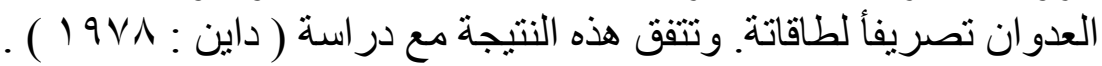

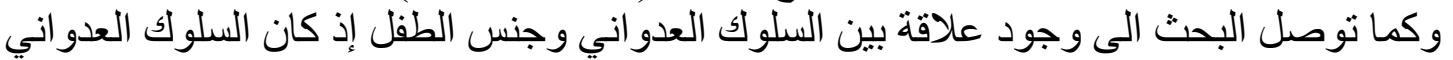
للذكور اعلى منه للاناث ، وتثلى العق هذه النتيجة مع نتائج در اسة (

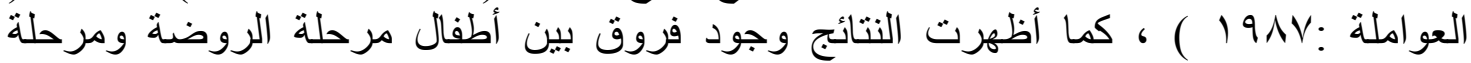

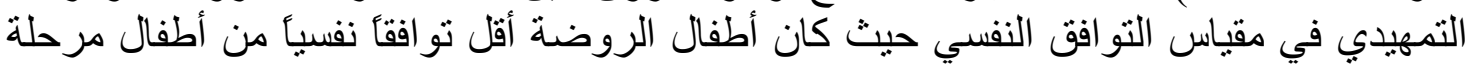
التمهيدي بينما كان أطفال مرحلة التمهيدي أكثر توافقأ من أطفال مرحلة الروضة الروضة في مقياس السلوك ألعدو اني . 
( ) اعداد بر امج خاصه لتخفيض السلوك العدواني للاطفال ذوي السلوك العدواني العالي و

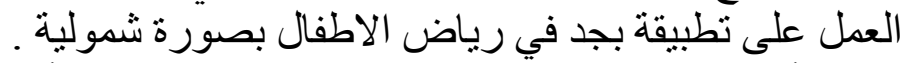

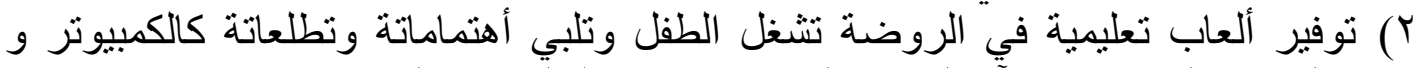

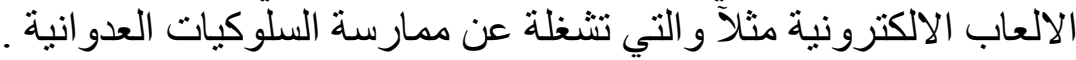

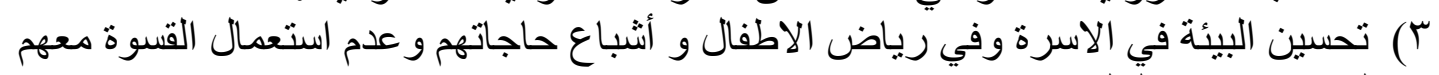

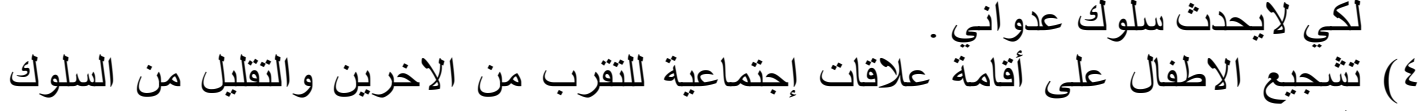

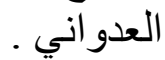
0) أن يستعملْ الو الدين أساليب الثواب و العقاب النفسي مع ابنائهم بالحوار الهادئ و الحزم في

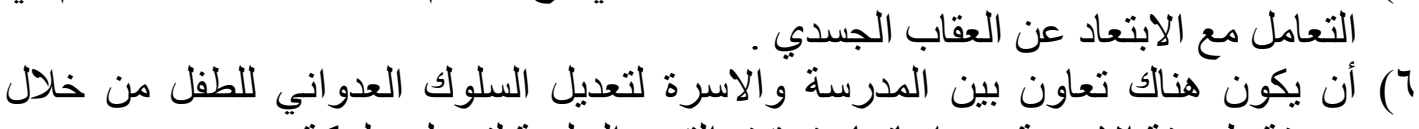

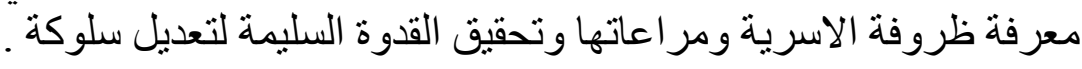

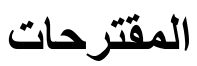

( ) إجر اء در اسة للسلوك العدو اني مع متغير ات أخرى كسوء المعاملة الو الدية .

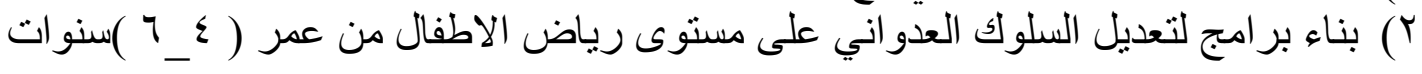
(ب) ) قياس السلوك العدو اني للطفل الوحيد في الاسرة .

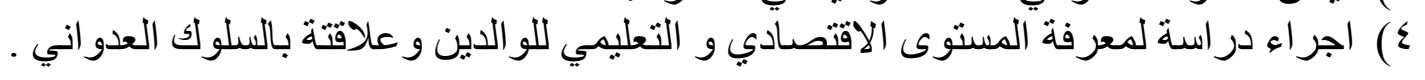


( ) الآلوسي، جمال حسين و علي خان، اميمة(ب/9 (1)): علم نفس الطفولة و المر اهقة، بغداد ،

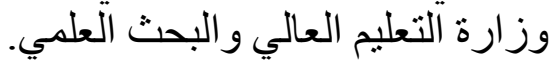

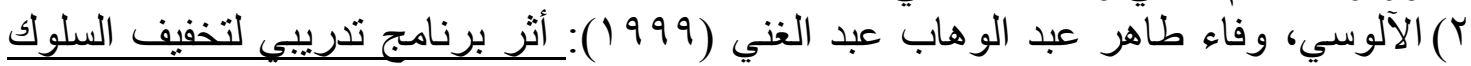

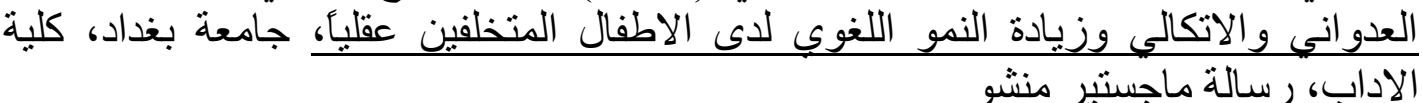

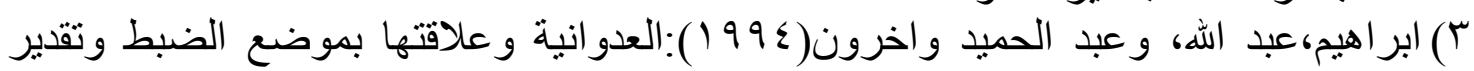

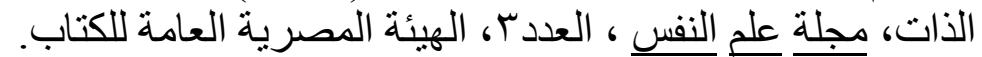

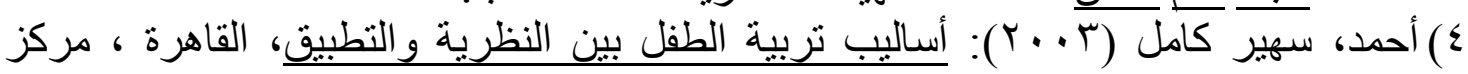
الاسكندرية للكتاب.

0) ألفت،محمد حقي(س 9 (1) ): علم النفس المعاصري، الاسكندرية ،جمهورية مصر العربية.

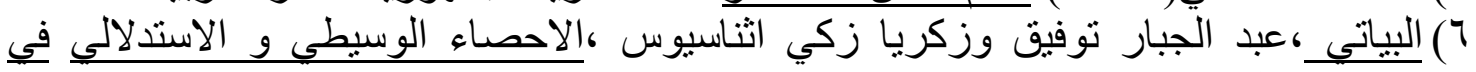

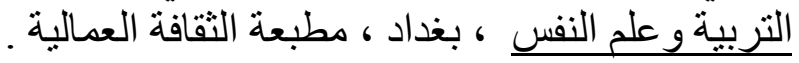

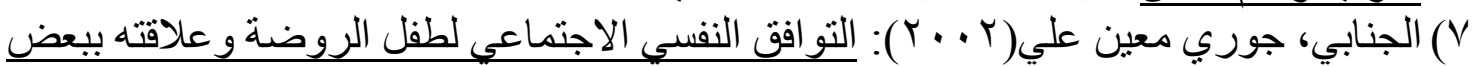

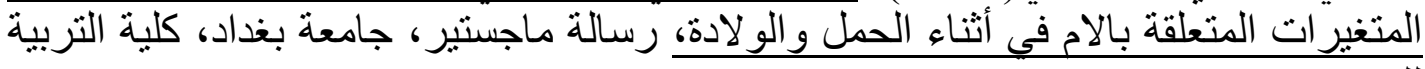
للبنات. A) دافيدوف، لندا (ب/9 1 ) : مدخل علم النفس ، ترجمه سيد الطواب وأخرون ، دارما كجر

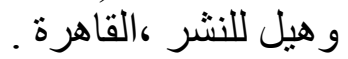

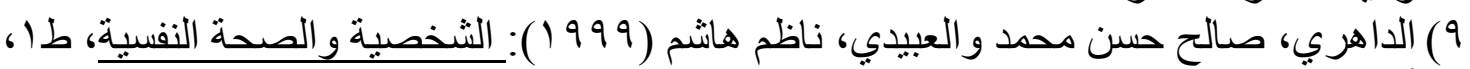

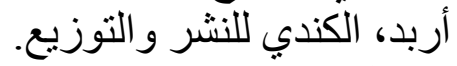

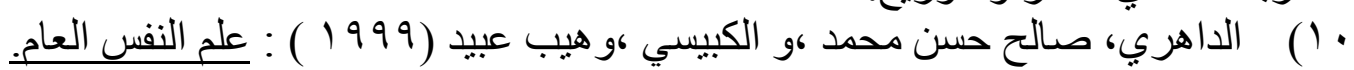

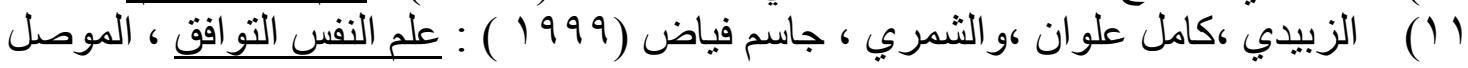

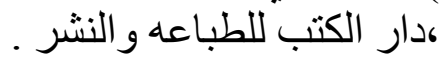

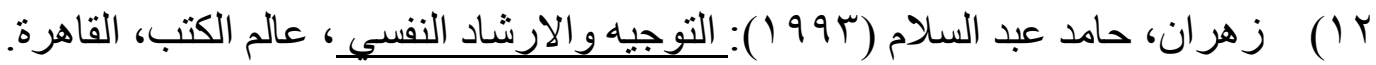

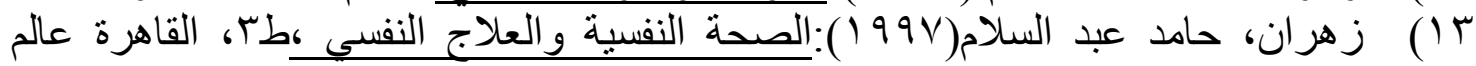
الكتب. ء ا ) السادة،جعفر علي مكي (د.ت):الصحة النفسية بين الفرد والمجتمع، مجلة الواحة ، العدد http://WWW.alwha.com ${ }^{\mu}$

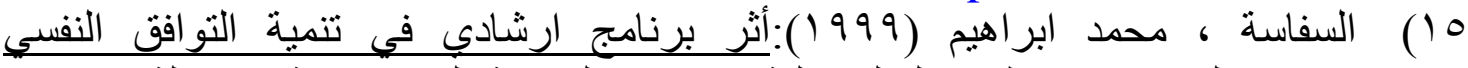

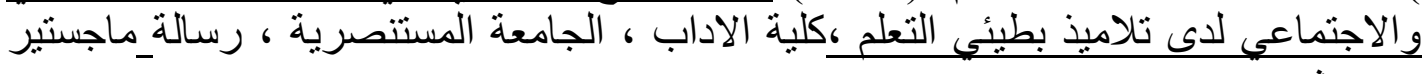
غير منشورة. 7 (1) السوداني ،يحي محمد سلطان (·99 (19)): قياس التو افت النفسي الاجتماعي لأبناء الثهداء

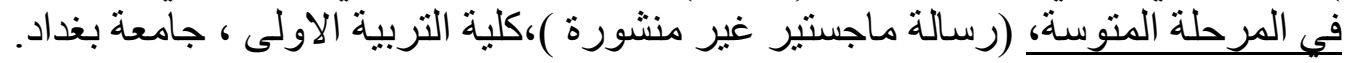

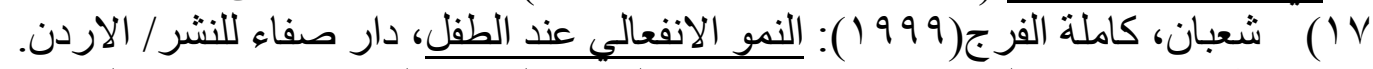

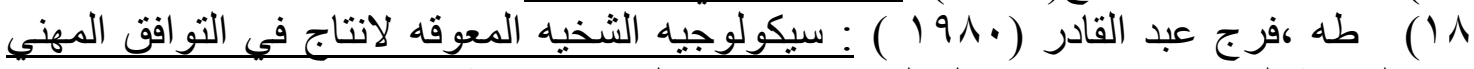

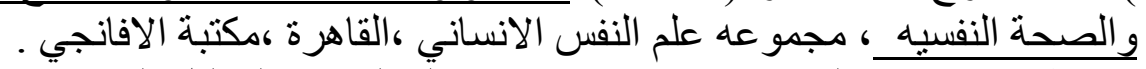

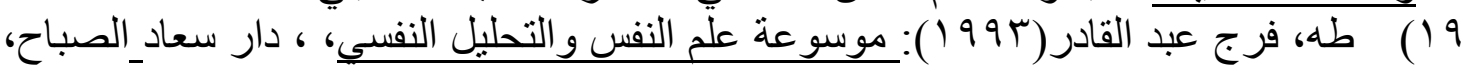
الكويت.

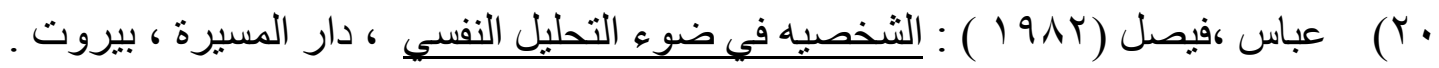


(Y) ( عبد الخالق،أحمد (910 ) ) : الاختبار ات الشخصية ، طץ ،القاهرة دار المعرفة الجامعية

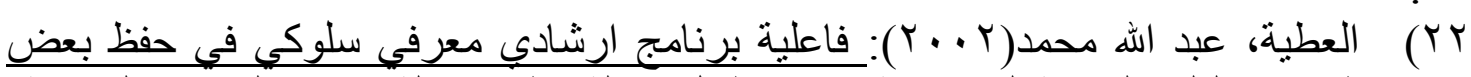

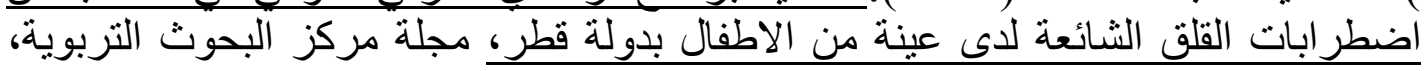

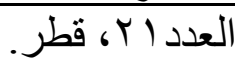

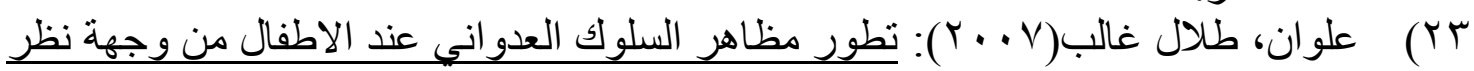

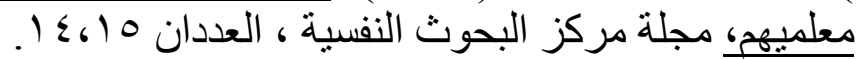

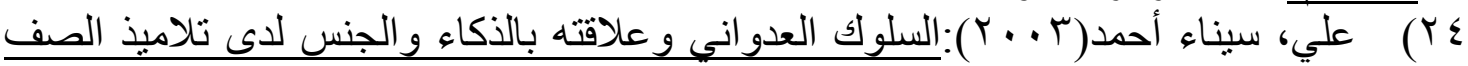

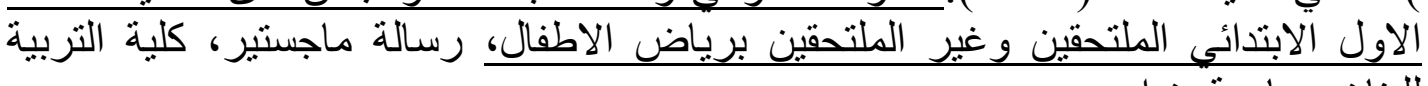

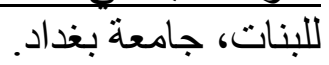

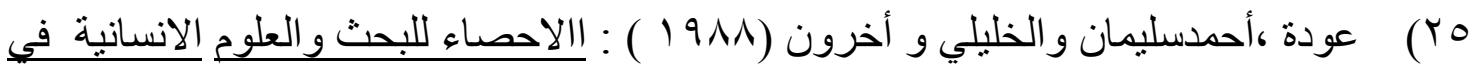

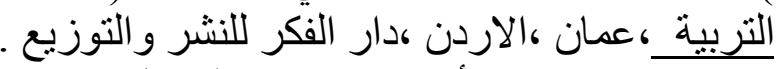

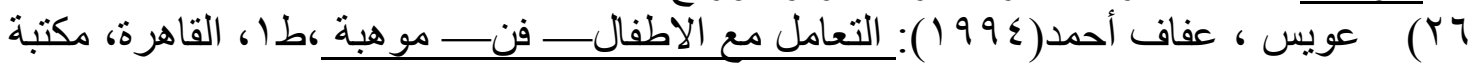

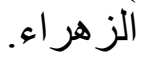

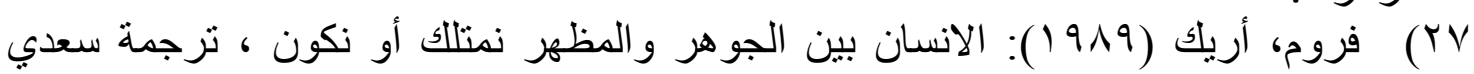

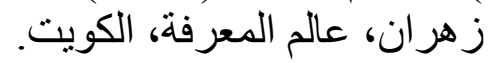

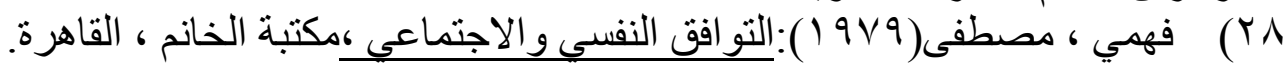

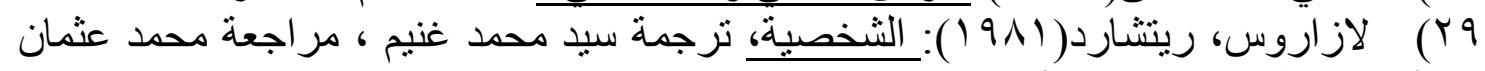

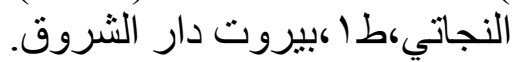

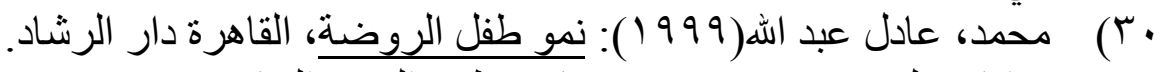

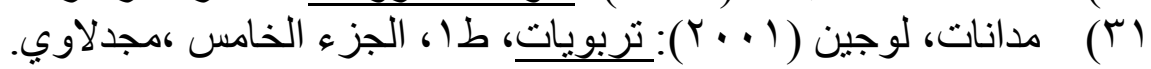

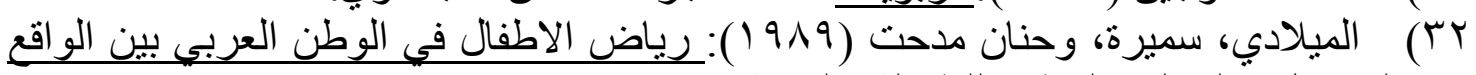

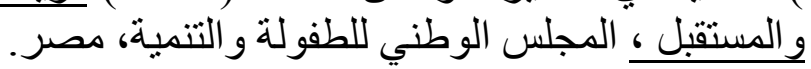

r

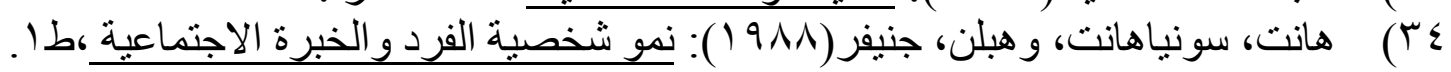

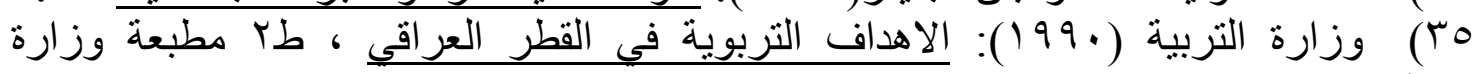

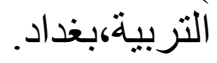

37-Dian, E.P..\&sally,W.(1978): Human development, Kosaido,CO.Ltd, Torque.

38- Steinmetz, (1987): Family violence: sussman M. B\& steimetz\&.(red),Hand book of Moriage and the family. 


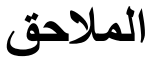

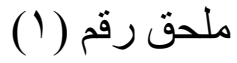

بسم الله الرحمن الرحيم

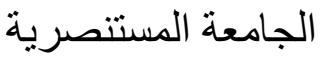

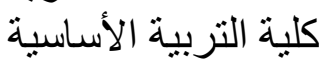

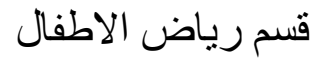

م/ استبانة

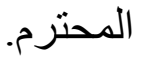

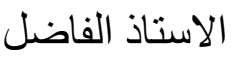

تروم الباحثة القيام بالبحث الموسوم(دور التوافق النفسي وعلاقته بالسلوك العدواني عند

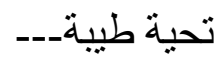

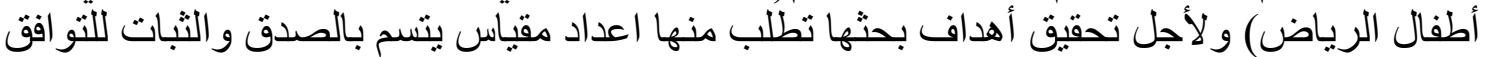

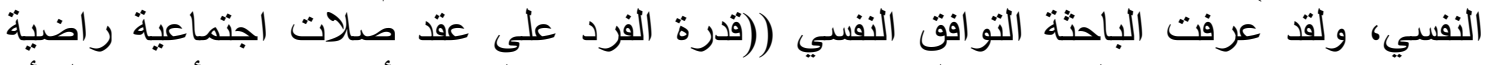

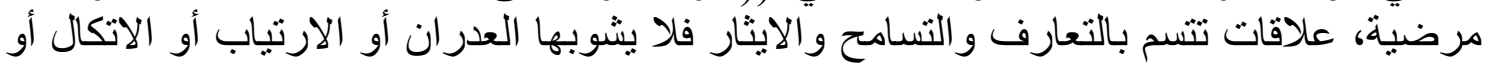

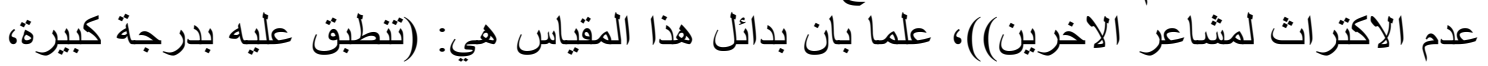

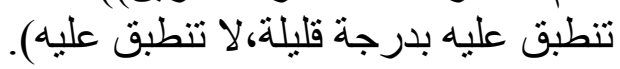

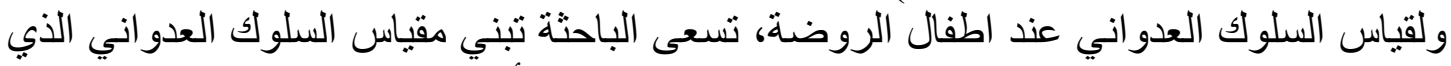

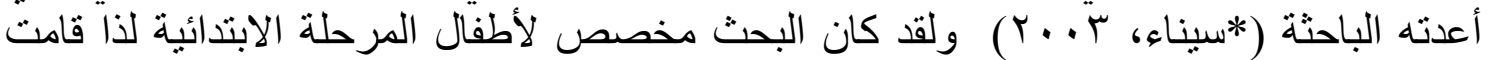

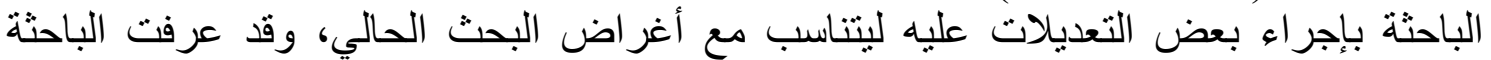

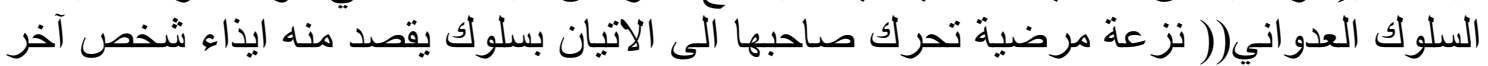

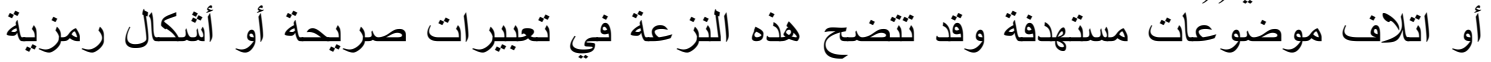

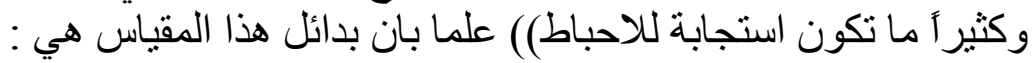

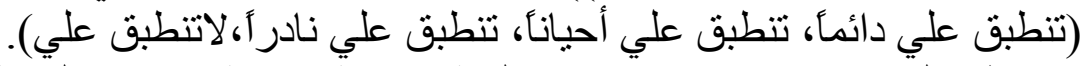

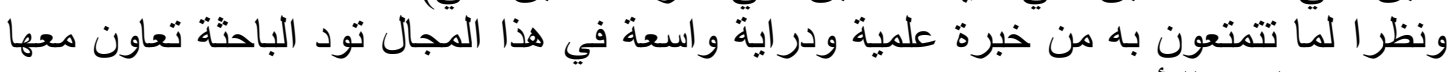

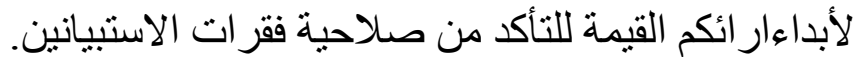

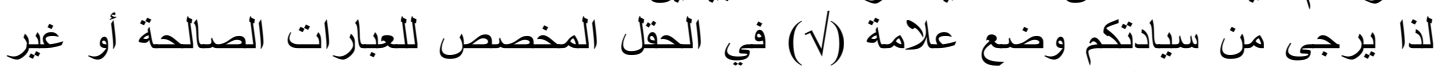
الصالحة مع ذكر التعديل المناسب

$$
\text { مع خالص شكرنا وتقديرنا }
$$




\begin{tabular}{|c|c|c|c|c|}
\hline قلتعديل & ضير & صالحة & 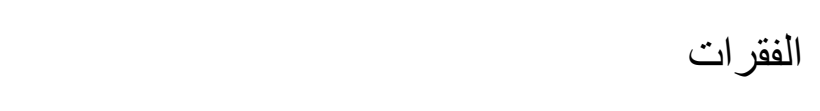 & $ت$ \\
\hline & & & يشعر بالخجل من الاخرين & -1 \\
\hline & & & يغضب بسر عة لاسباب تافهة & $-r$ \\
\hline & & & يبكي عندما يفشل في عمل معين & $-r$ \\
\hline & & & يشعر بالذنب عندما يشعر بالقلق & $-\varepsilon$ \\
\hline & & & يعترف بالخطأ اذا ما ارتكبه & -0 \\
\hline & & & لا ير اوده القلق لغياب و الديه & -7 \\
\hline & & & يتحمل المسؤولية تجاه حاجاته الثخصية في الروضة & $-\mathrm{V}$ \\
\hline & & & يتمتع بثقة عالية بالنفس في اداء نشاطات الروضة & $-\Lambda$ \\
\hline & & & بشعر بالغيرة من الاطفال الاخرين & -9 \\
\hline & & & يعتمد على نفسه في تلبية حاجاته الثخصية & $-1 \cdot$ \\
\hline & & & يعاني من قلة الانتباه & -11 \\
\hline & & & يكسر ما حوله من أنشياء عندما لا تلبى حاجاته & $-1 Y$ \\
\hline & & & يقود أقر انه عند اللعب والانشطة & -14 \\
\hline & & & يقدم المساعدة لاقر انه في الروضة عند الحاجة & $-1 \varepsilon$ \\
\hline & & & يستمتع باللعب مع أقر انه & -10 \\
\hline & & & يتشاجر مع أقر انه لاسباب بسيطة & -17 \\
\hline & & & ينسجم مع أقر انه في الاعمال المشتركة & $-1 \mathrm{~V}$ \\
\hline & & & مطيع لمعلمته & -11 \\
\hline & & & يحب جميع أقر انه في الصف & -19 \\
\hline & & & يتعاطف مع أقر انه ما اذا أصابهر مكروه & $-T^{-}$ \\
\hline & & & يرفض عبث أقر انه بممنلكات الاخرين & $-r)$ \\
\hline & & & ينقاد لقرار ات الاخرين بسهولة واستمر ار & $-T^{-}$ \\
\hline & & & يحرص على حاجاته ويهمل حاجات الاخرين & $-T^{M}$ \\
\hline & & & يستئذن حين يستخدم ممتلكات اقر انه & $-r \varepsilon$ \\
\hline & & & يحاول ان يتز عم مجمو عة اللعب & $-r_{0}$ \\
\hline & & & يرتبك عندما يتحدث امام زملائه في الصف & $-T^{-1}$ \\
\hline & & & يشكو الى المعلمة من مضايقة الاخرين & $-4 V$ \\
\hline & & & يفتقد معلمته اذا غابت عن الروضة & 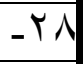 \\
\hline & & & يشعر بأنه محبوب من المعلمات & $-r_{9}$ \\
\hline & & & يختلق مشكلات لأقر انه من أجل اشباع حاجاته & $-\Gamma$. \\
\hline
\end{tabular}


مقياس السلوك العدواني

\begin{tabular}{|c|c|c|c|c|}
\hline 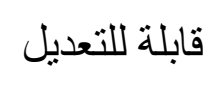 & 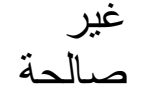 & 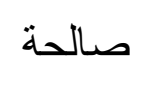 & 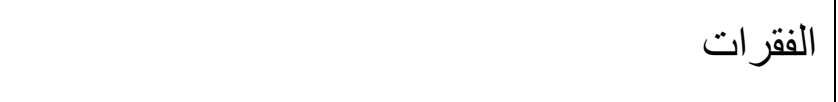 & ت \\
\hline & & & يضرب الاطفال باليد لأتفه الاسباب & -1 \\
\hline & & & يدفع الاطفال بهذف ايذائهر & $-Y$ \\
\hline & & & يشتم الاطفال الاخرين & $-\pi$ \\
\hline & & & يتفوه بكلمات نابية على الاطفال & $-\varepsilon$ \\
\hline & & & يرفس الاطفال الاخرين & -0 \\
\hline & & & يكسر أدو ات أو لعب الاخرين بهذف الايذاء & -7 \\
\hline & & & يعبث بحاجات الاطفال بقصد الايذاء & $-y$ \\
\hline & & & يكسر الاثاث بتعدد & -1 \\
\hline & & & يضرب نفسه عندما ينفعل & -9 \\
\hline & & & يقرص الاطفال بقصد إذائهم & $-1 \cdot$ \\
\hline & & & يعض الاطفال الاخرين & -11 \\
\hline & & & يعض نفسـه عندما ينفعل & -14 \\
\hline & & & يبكي لاتفه الاسباب كي يزعج الاخرين & -14 \\
\hline & & & يأخذ ما يملكه الاطفال الاخرين عنوة & $-1 \leqslant$ \\
\hline & & & يتشاجر مع الاطفال & -10 \\
\hline & & & يتهم الاطفال بقصد ايذائهم أومعاقبتهم من الكبار & -17 \\
\hline & & & يتمنى إيقاع الاذى بالاخرين & $-1 \mathrm{y}$ \\
\hline & & & يخفي حاجات الاخرين بقصد إيذائهم & -11 \\
\hline & & & يمزق كتب ودفاتر الاطفال & -19 \\
\hline & & & يستهزئ بالاطفال & $-r$. \\
\hline & & & يثير الفتن بين الاطفال & -4 \\
\hline & & & الارضع معوقات أمام الاطفال بقصد إيقاعهم على & $-r Y$ \\
\hline & & & يبصق على الاطفال & $-T^{-}$ \\
\hline & & & يخوف الاطفال الاخرين & $-r \leqslant$ \\
\hline & & & و والحرم كات التقليدية مز عجة للاخرين كالإيماءات & $-r_{0}$ \\
\hline & & & يشت بالاطفال عندما يتعرضون لأذى & $-r 7$ \\
\hline
\end{tabular}




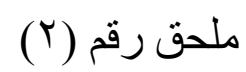

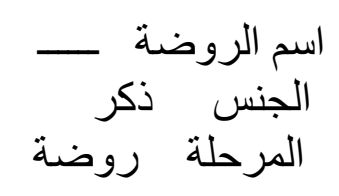

الجامعة المستتصرية كلية التربية الأساسية

قسم رياض الاطفال

\section{م/إستبانة}

حضرة المعلمة الفاضلة

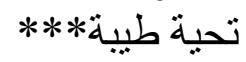

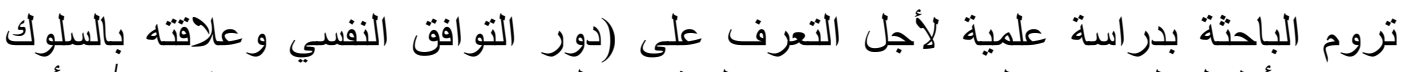

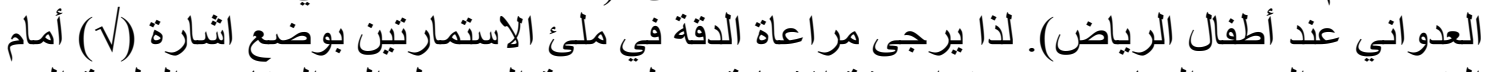

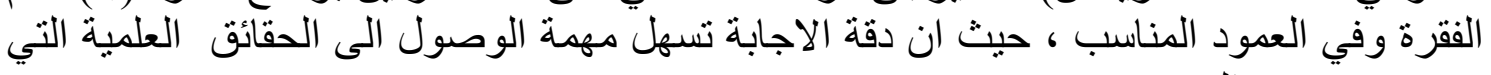

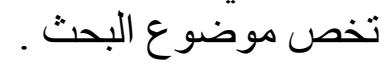

\section{شاكرين تعاونكم معنا خدمة للعملية التربوية و العلمية}

ملاحظة:- يقصد بالتوافق النفسي (( قدرة الفرد على عقد صلات اجتماعية راضية

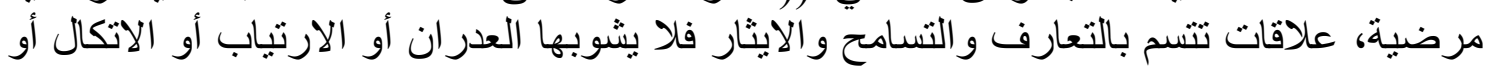
عدم الاكتراث لمشاعر الاخرين)).

أما السلوك العدو اني فيقصد بها(( نزعة مرضية تحرك صاحبها الى الاتيان بسلوك يقصد

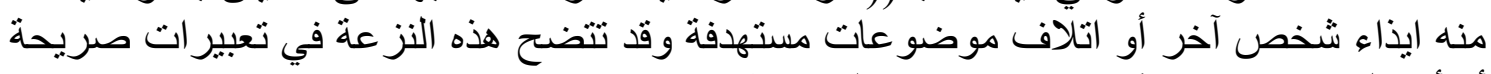
أو أنشكال رمزية وكثير أ ما تكون استجابة للاحباط)).

الباحثة 
جمل: الآراب / العرو r 11 10

أولاً:- مقياس التوافق النفسي

\begin{tabular}{|c|c|c|c|c|}
\hline تلنطبق & تبطبق تلبة قليه & تبطرجة كبيرة & 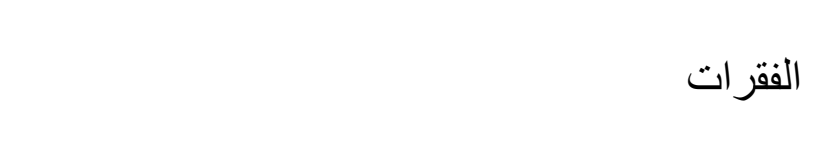 & $ت$ \\
\hline & & & يشعر بالخجل من الاخرين & -1 \\
\hline & & & يغضب بسر عة لاسباب تافهة & $-Y$ \\
\hline & & & يبكي بشدة عندما يفشل في عمل معين & $-\Pi$ \\
\hline & & & يشتعر بالذنب عندما يشعر بالقلق & $-\varepsilon$ \\
\hline & & & يعترف بالخطأ اذا ما ارتكبه & -0 \\
\hline & & & يتحمل المسؤولية تجاه حاجاته الثخصية في الروضة & -7 \\
\hline & & & يتمتع بثقة عالية بالنفس في اداء نشاطات الروضة & $-V$ \\
\hline & & & يشعر بالغيرة من الاطفال الاخرين & $-\wedge$ \\
\hline & & & يعتمد على نفسـه في تلبية حاجاته الثخصية & -9 \\
\hline & & & يختلق الاعذار غير الصحيحة & $-1 \cdot$ \\
\hline & & & يكسر ما حوله من أشياء عندما لا تلبى حاجاته & -11 \\
\hline & & & يخالف انظمة الروضة وتعليماتها & $-1 Y$ \\
\hline & & & يقدم المساعدة لاقر انه في الروضة عند الحاجة & -114 \\
\hline & & & بستمتع باللعب مع أقر انه & $-1 \varepsilon$ \\
\hline & & & يتشاجر مع أقر انه لاسباب بسيطة & -10 \\
\hline & & & يتردد في المشاركة في الاعمال الجماعية & -17 \\
\hline & & & مطيع لمعلمته & $-1 V$ \\
\hline & & & يتعاطف مع أقر انه ما اذا أصـابهم مكروه & -11 \\
\hline & & & يرفض عبث أقر انه بممتلكات الاخرين & -19 \\
\hline & & & ينقاد لقرار ات الاخرين بسهولة و استمر ار & $-r \cdot$ \\
\hline & & & يحرص على حاجاته ويهمل حاجات الاخرين & -41 \\
\hline & & & يستنذن حين يستخدم ممتلكات اقر انه & $-T^{-}$ \\
\hline & & & يرتبك عندما يتحدث امام زملائه في الصف & $-M T$ \\
\hline & & & يشكو الى المعلمة من مضايقة الاخرين & $-Y \leqslant$ \\
\hline & & & يفتقد معلمته اذا غابت عن الروضة & -10 \\
\hline & & & لا ير اعي مشاعر الاخرين & $-Y T$ \\
\hline
\end{tabular}


ثانياً:- مقياس السلوك العدواني

\begin{tabular}{|c|c|c|c|c|c|}
\hline لانطبق & نادِبه & عليطبق & عليهبه & 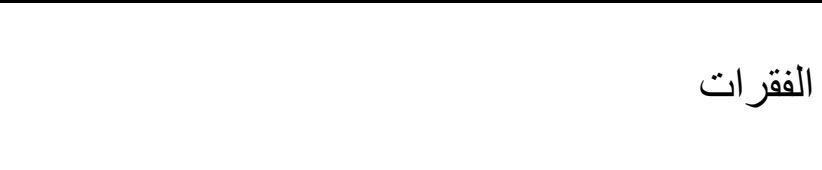 & ت \\
\hline & & & & يضرب الاطفال باليد لأتفه الاسباب & -1 \\
\hline & & & & يدفع الاطفال بهدف ايذائهم & -4 \\
\hline & & & & بشتم الاطفال الاخرين & $-\mu$ \\
\hline & & & & يتفوه بكلمات نابية على الاطفال & $-\varepsilon$ \\
\hline & & & & يرفس الاطفال الاخرين & -0 \\
\hline & & & & يكسر أدوات أو لعب الاخرين بهذف الايذاء & -7 \\
\hline & & & & يعبث بحاجات الاطفال بقصد الايذاء & $-\mathrm{-V}$ \\
\hline & & & & يكسر الاثاث بتعمد & $-\Lambda$ \\
\hline & & & & يضرب نفسه عندما ينفعل & -9 \\
\hline & & & & يقرص الاطفال بقصد إذائهم & $-1 \cdot$ \\
\hline & & & & يعض الاطفال الاخرين & -11 \\
\hline & & & & بعض نفسه عندما ينفعل & $-1 Y$ \\
\hline & & & & يبكي لاتفه الاسباب كي يز عج الاخرين & -14 \\
\hline & & & & يأخذ ما يملكه الاطفال الاخرين عنوة & $-1 \varepsilon$ \\
\hline & & & & يتثاجر مع الاطفال & -10 \\
\hline & & & & يتهم الاطفال بقصد ايذائهم أومعاقبتهم منالكبار & -17 \\
\hline & & & & يتمنى إيقاع الاذى بالاخرين & $-1 V$ \\
\hline & & & & يخفي حاجات الاخرين بقصد إيذائهم & -11 \\
\hline & & & & يمزق كتب ودفاتر الاطفال & -19 \\
\hline & & & & يستهزئ بالاطفال & $-Y$. \\
\hline & & & & يثير الفتن بين الاطفال & $-Y_{1}$ \\
\hline & & & & الارضع معوقات أمام الاطفال بقصد إيقاعهم على & $-T^{-}$ \\
\hline & & & & يبصق على الاطفال & - \\
\hline & & & & بخوف الاطفال الاخرين & $-Y \leqslant$ \\
\hline & & & & و الحرم بات التقليدية مزعجة للآخرين كالإيماءات & $-Y 0$ \\
\hline & & & & يشّت بالاطفال عندما يتعرضون لأذى & $-r T$ \\
\hline
\end{tabular}

